Çukurova Üniversitesi Eğitim Fakültesi Dergisi

Vol: 50 Numb: 2 Page: 1100-1126

https://dergipark.org.tr/tr/pub/cuefd

\title{
The Moderating Role of Psychological Empowerment on the Relationship between Individualism-Collectivism perceptions and Burnout of Teachers
}

\author{
Sebahattin KILINÇ ${ }^{a^{*}}$ (ORCID ID - 0000-0003-4451-9309) \\ Serdar YENER ${ }^{\mathrm{b}}$ (ORCID ID - 0000-0003-1413-7422) \\ ${ }^{a}$ Milli Savunma Üniversitesi, Ankara/Türkiye \\ ${ }^{b}$ Sinop Üniversitesi Boyabat IiBF, Sinop/Türkiye
}

CrossMark

\section{Article Info}

DOI: $10.14812 /$ cufej.685392

\section{Article history:}

Received 05.02.20

Revised 02.08.21

Accepted 04.11.21

Keywords:

Academic Success, Individualism,

Collectivism, Burnout,

Psychological Safety.

\begin{abstract}
Many studies revealing that sociocultural norms affect teachers' perceptions and behaviors lead us to question the role of different variables in the perception of burnout. It is observed that the perception of burnout, which has been investigated for nearly 50 years, affects not only health workers, but also service sectors such as education, banking and care services. It is generally emphasized in researches that the perception of burnout observed in studies in Western individual societies can also be observed in Eastern collectivist societies. In most of studies related to burnout syndrome, psychological empowerment is accepted as a predictor however no study offers that individualistic trends may also affect burnout. Besides the effects of collectivist trends have not been studied. Within the framework of the theory of conservation of resources, the effect of individual and collectivist tendencies on burnout and the moderator role of psychological empowerment perception were questioned in this study. In the study, 16 item individualism and collectivist perception scale, which was validated in Turkish by Uzbek (2010), 22 item The Maslach Burnout Scale (MTÖ) which was validated in Turlkish by Ergin (1992), 12 item psychological empowerment scale, which was validated in Turkish by Altindish and Özutku (2011) were used.

207 teachers working in public schools consisted the sample group of research. The data gathered through face to face surveys were analyzed by SPSS 22 and Process 3.= version macro. According to the results of tests mediation role of psychological empowerment is observed between individualism and burnout but has not been observed between collectivism and burnout
\end{abstract}

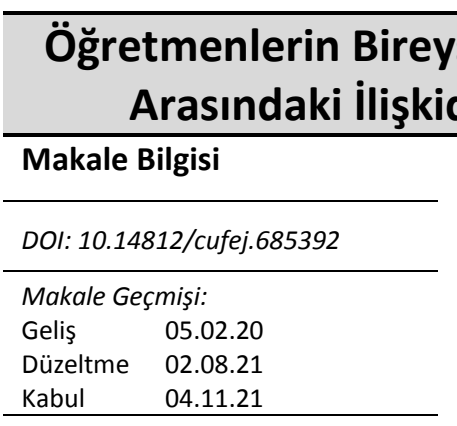

Anahtar Kelimeler: Akademik başarı, Bireyselcilik, Kolektivizm, Tükenmişlik, Psikolojik Güçlendirme.
Sosyokültürel normların öğretmenlerin algılarını ve davranışlarını etkilediğini ortaya koyan birçok araştırma tükenmişlik algısında farkı değişkenlerin rolünü sorgulamamıza yol açmaktadır. Alanyazında yaklaşık 50 yıldır araştırılan tükenmişlik algısının sadece sağlık çalışanları değil eğitim, bankacılık, bakım hizmetleri gibi hizmet sektörlerini de etkilediği gözlemlenmektedir. Genellikle Batılı bireysel toplumlarda yapılan çalışmalarda gözlenen tükenmişlik algısının Doğulu kolektivist toplumlarda da gözlenebileceği araştırmalarda ortaya konulmaktadır. Tükenmişlik algısının farklı çalışmalarda psikolojik güçlendirme sayesinde azalabileceği ortaya konulurken bireysel eğilimlerin bağımsız değişken rol oynayabileceği dikkate alınmamıştır. Kolektivist eğilimlerin ise hemen hemen hiç kullanılmadığı gözlenmiştir. Kaynakların korunumu çerçevesinde bu çalışmada bireysel ve kolektivist eğilimlerin tükenmişlik üzerindeki etkisi ve bu etkide psikolojik güçlendirme algısının düzenleyici rolü sorgulanmıştır. Araştırmada Ergin (1992) tarafından Türkçe geçerlik ve güvenirlik çalışması yapılan 22 maddeden oluşan Maslach Tükenmişlik Ölçeği (MTÖ) Özbek (2010) tarafından Türkçe geçerlik ve güvenirlik çalışması yapılan 16 maddelik bireselcilik ve kolektivist algı ölçeği, Altındiş ve Özutku (2011) tarafından Türkçe geçerlik ve güvenirlik çalışması yapılan 12 
maddelik psikolojik güçlendirme ölçeği kullanılmıştır. Kamu okullarında görev yapan 207 öğretmen araştırmanın örneklemini oluşturmaktadır. SPSS 22 ile kullanılan Process 3.0 makrosunda yapılan analiz sonuçlarına göre Psikolojik güçlendirmenin bireyselcilik ve tükenmişlik arasında güçlü bir düzenleyici etkisi gözlenirken kolektivizm ve tükenmişlik arasında düzenleyici etkisi gözlenmemiştir.

\section{Introduction}

Chronicization of stress caused by different causes in individuals causes many disorders and burnout is one of these disorders. The perception of satisfaction of the service provided to individuals and the chronic pressure of the service sector on employees have given the literature burnout syndrome (Freudenberger, 1980). Burnout syndrome, which was observed intensely in counselors and nurses in the health sector in the beginning, can be observed with many symptoms such as emotional bankruptcy of the employees, despair in almost many areas of life, having a sense of cynicism and regression in the abilities and skills they used to have (Maslach \& Jackson, 1981). Freudenberger (1975), who observed with longitudinal studies that individuals who started to work as idealistic and lively individuals at the beginning, drifted into burnout after a while, defined chronic stress as the main determinant by examining the work environment of the employees and the characteristics of the job. Stress is defined as the individual's response to the factors (Stressor) that negatively affect the individual's normal state, with physical, emotional and other dimensions (Yener, 2016). In the studies conducted at the beginning, it was observed that the employees who experienced burnout felt empathy towards the individuals they served, they tried to add more than the responsibilities required by the job to meet their treatment, expectations and wishes, and therefore institutional resources could not support this process and they could not receive help and support. The fact that these employees, who identify themselves with their work, cannot find many resources (time, materials, feedback, financing, etc.) they need and cannot separate the boundaries of their work and private life, makes the pressure of their work permanent. After Freudenberger, with Maslach and Jackson's efforts to develop a measurement tool and measure the perception of burnout in other service sectors, emotional exhaustion, which are the sub-dimensions of burnout perception, have been brought into the literature with the perception of personal failure and depersonalization. Studies showing that teachers can experience burnout in the education sector, which is an important area of the service sector, have started to become widespread (Wu, 2020). In these studies, it is revealed that teachers may experience burnout due to high job stress and this may negatively affect their mental health. As the symptoms of burnout and related disorders in teachers increased, studies on teacher burnout began to increase (Barutçu \& Serinkan, 2013). Another result that emerged in these studies on teachers is that the psychological pressure on teachers is increasing because the expectations from teachers are very high in every society. In Turkey too, which has felt the impact of global transformations, many pressure factors (stress sources) have started to emerge, especially in education and training life. Expectations from students, family opportunities and differences in children's upbringing, discourses of social degeneration, and ever-changing educational policies and strategies create a lot of pressure and stress on teachers. Considering the research and observations, when the determinants of many negative examples are taken into consideration, the symptoms of burnout syndrome can also be observed in teachers (Durak \& Seferoğlu, 2017).

The effect of the sociocultural characteristics of the society in which the individual lives on the behavior of the individual is revealed in many studies (Yener \& Arslan, 2017; Kasa \& Hassan, 2016). After Hofstede $(1980,1984)$ brought the cultural taxonomy to the literature, studies to define the effects of sociocultural factors on the determinants of an individual's psychology and behavior gradually increased. Hofstede, who basically classifies cultures with dimensions such as power distance, masculinity-femininity, individualism-collectivism, mood balance, risk-taking and conservative behavior, offers us clues to analyze behaviors and perceptions. In this framework, factors such as the fact that studies on burnout are mostly carried out in the service sector in individual cultures, and the spread of our studies after globalization (degeneration of collectivism perception) formed the starting point of this study. Based on Hobfoll's (1989) "Conservation of Resources Theory", it was thought that individuals could use the sociocultural functions of the society they live in to conserve their resources or consume 
their resources due to the absence of sociocultural functions when faced with stressors that threaten the resources they have while maintaining their lives. In addition, since burnout is experienced as a result of individuals depleting their resources due to chronic stress, it was thought that the individual would not experience burnout as rehabilitated or could live at lower levels thanks to psychological empowerment. Within the framework of the results obtained from the teachers' cultural norms, psychological empowerment and burnout literature, it is suggested in this study that psychological empowerment can regulate the effect of individual and collectivist tendencies on burnout within the framework of the Conservation of Resources Theory.

\section{Burnout}

The definitions of the concept of burnout in the literature are based on the results of Freudenberger's applications in 1975 (O'Brien, 2010). Freudenberger defined the concept of burnout after observing the negative changes experienced by a group of idealistic counselors who started to work voluntarily in a drug counseling clinic after a while. Freudenberger, who tried to describe the problems experienced by consultants such as chronic headaches, intestinal and digestive problems, negative behaviors towards patients, and low self-esteem and self-confidence after a while, reported his observations. The researcher stated that employees who work and dedicate themselves to the recovery or well-being of another person, such as the consultancy job at the drug clinic mentioned above, experience stress and experience burnout when this stress becomes chronic. Later, with the studies of Cherniss, it was seen that the validity of the concept of burnout was tested in many business lines in the service sector (Cherniss, 1980). In Cherniss (1980), just like Freudenberger, they observed that service sector employees who initially had idealistic and positive emotions had negative emotions after a while, experienced cynicism, became insensitive and lost interest in the task. Another emphasis in Cherniss's work is that the lack of autonomy of service workers in public and institutionalized enterprises and the fact that their salaries are standard increases this stress. In addition to the studies of Freudenberger (1975), who claimed that the personal characteristics of the employee affect the job outlook or evaluation processes, Cherniss (1980) claimed that organizational factors such as the employee's autonomy and control over the job may also be effective on burnout. Cherniss (1980) argues that the autonomy that service workers will need to reduce the pressure of their duties may play a regulatory function.

Maslach and Jackson (1981), the owner of the scale, which is widely used in the literature to measure the perception of burnout, define burnout as the experience that an employee has experienced as a result of chronic work-related stress, which he or she is exposed to for a long time in sectors where they use their emotions intensely. In this process, it has been reported that the employee is physically and emotionally worn out, becomes tense due to the responsibility of thinking about the well-being of others due to his duty, cannot respond to increasing demands, and loses his beliefs, desires and ideals for work (Demerouti, Mostert, \& Bakker, 2010). In addition to their responsibilities to the individuals who receive service in the above-mentioned conditions, service sector employees are pushed into despair and intimidation in cases where their corporate resources are insufficient, if they do not have managerial authority for the job, when they are not rewarded or when they cannot receive a reward for their efforts (Yener \& Arslan, 2017). Although the process is seen as emotion-oriented, Maslach claimed that exhausted employees will also experience physical discomfort. It has been claimed that physical ailments such as constant colds and flu, musculoskeletal disorders, stomach disorders, hypertension, and sleep disorders may be among the possible consequences of Exhaustion (Maslach, 2003).

From the point of view of organizations, it is inevitable for employees to become alienated from work, become depersonalized, and have a sense of cynicism by showing signs of Burnout after a while, negatively affecting their performance. Other indirect consequences are that employees leave their jobs when they have the opportunity to experience these experiences, stay away from work for long periods due to health reasons, and are mentally isolated even if they are physically present. As a result of Maslach's studies to measure the perception of Burnout, he suggested that Burnout consists of a 3- 
component structure, which he called emotional Burnout, depersonalization and personal failure. Emotional Burnout occurs when the individual feels that his emotional resources are completely depleted. At this stage, it is common for the individual to show signs of physical, emotional, and mental Burnout. One of the symptoms is that the individual cannot find enough energy and desire to do anything. Disruption of eating habits, chronic headaches, intestinal and digestive disorders are other symptoms. Hopelessness, helplessness, loss of expectations, and the complete disappearance of the belief that everything will be okay are common symptoms in business life (O'Brien, 2010). Being stuck in one's own context in a hopeless and helpless way and not being able to meet the expectations of others is called cold empty shell by Maslach. It is claimed that at this stage, irritability, tension, depression, substance use and suicidal tendencies may be experienced (Maslach, 2003). In the last stage of Burnout, individuals experience a decrease in their self-efficacy and perceptions of success. Employees in the service sector, at this stage, have a perception of inadequacy in meeting the expectations of the individuals they serve. Exhausted employees, who are in dilemma about their professional qualifications, often fail by having difficulty in making decisions. At this stage, the individual may feel inadequate self-confidence and self-esteem not only in business life but also in other areas of life.

Considering the observations, the symptoms initially observed by Freudenberger (1975) in the health sector, which is within the service sector, were also observed in the lines of business in the different service sectors, such as banking and teaching, in the following years. Factors arising from the characteristics of the sector, namely the fact that the serviced segment is human, and the service to be provided by the employee and the waiting for solutions to their problems or needs, distinguish these sectors from other sectors. Consciousness, compassion, etc., which are some basic characteristics arising from the nature of human beings characteristics (Neff, 2011) cause the employee to put himself in the place of the other party. It is claimed that Burnout will occur as a result of the stress caused by the employee who puts himself in the place of the receiving party, thinking that he cannot meet his expectations due to the effect of the job, the organization and other factors, and this stress becomes chronic (Freudenberger, 1975). Considering that the determinant that triggers the process is stress, it is necessary to define stress. Stress is defined as the reactions of individuals to the factors that affect their ordinary conditions and cause them to change their lives (Eren, 1998). In order for the individual to affect his ordinary life, the initiating factor called the stressor must demand more from the individual's resources (Baltaş \& Baltaş, 1987).For example, the fact that a single mother who is supposed to be at work at 08:00 in the morning has to take her child for the examination at 09:00 can create a stressor effect. If the mother is a wage worker, her time resources may not allow her to solve this situation on her own. Therefore, the mother will either have to send her child for examination through a relative or get permission from her employer. The absence of any suitable relatives is the case when the mother does not allow network resources in this direction to solve this problem. The employer's refusal to allow shows that the mother also lacks time and resources for work. Conversely, in a situation where it is difficult for the mother to solve it alone, the fact that an understanding employer can tolerate the mother's situation and allow the child during the treatment process means that the mother gives a destructive reaction to the stressor, that is, prevents the occurrence of stress. Based on this example, the fact that the mother does not have the resources that she will need not only for the examination problem of her child, but also for many problems, after a while, the stressors create stress, and the constant state of stress causes the stress to become chronic.

Factors called stressors that cause individuals to make changes in their lives have been discussed in many studies and even Thomas Holmes and Richard Rahe developed a stress inventory. Bootzin and Loftus (1983) scored the factors that cause stressors in the lives of individuals by emphasizing this inventory. To give an example of various factors that were scored between 0 and 100 points as a result of this scoring, the factor of leaving the job was evaluated as 50 points. Job design or changing the work environment was evaluated as 39 points, change in job responsibility 29 points, and factors related to the supervisor were evaluated as 23 points. At the level of 150-200 points in the stress index, the individual characteristics of the individual, namely psychological resilience, etc. while it is observed that stress becomes chronic with the effect of its characteristics, it is claimed that the individual experiences 
psychological discomfort when stressors have an effect of 300 points on the individual (Bootzin \& Loftus, 1983). Looking at this inventory, considering that the job-related factors are 187 points, it is thought that work is really important in an individual's life. In this respect, when it is aimed to minimize the effect of stress in the life of the individual, it may be necessary to examine the determinants of work. Strategies that will make work-oriented determinants have a positive effect on the individual are increasingly being researched in the literature. Research on leadership, structural factors and colleagues within the framework of the organization is becoming widespread. Topics such as leader member interaction, support, structural and psychological empowerment can be given as examples. In this study also, the effect of individual and collectivist tendencies on teachers' Burnout perceptions and the moderator role of psychological empowerment in this relationship process were investigated.

\section{Psychological Empowerment}

Empowerment refers to support for employees to take part in decision-making processes, facilitate their access to resources, and develop their talents and skills (Conger and Kanungo, 1988). Empowerment is examined under two headings in the literature as structural empowerment and psychological empowerment.

Structural empowerment is based on Kanter's Theory of Structural Power in Organizations (Kanter, 1993). The theory proposes that formal or informal power sources in organizations can play a role in empowering personnel by creating organizational structures. The structures of organizations that encourage the participation of employees in decision-making processes, their individual and professional development, and the formation of career development can be given as examples of structural strengthening tools. The sharing of the determiners who have will over the resources and defined as power within the organization by the employees defines the process of facilitating access to information, support and other resources. The fact that employees have access to the resources they will need to fulfill their responsibilities makes resource deprivation not a stressor. Financial resources, materials, conditions of the working environment, time etc. factors can be examples of these resources. Since the interlocutors of the employees, especially those of the service sector, are human, it is thought that they add not only organizational resources but also individual resources to the process. It is assumed that the employee, who is the addressee of the service, has empathy, feels conscientious responsibility and directs with all the resources at his disposal in order to meet the requests or needs of the party. If the employee cannot meet the demands and needs of the service recipient with the resources he has alone, the negative process that he will experience can be overcome with structural support. Structural supports to be given to the employee, as stated above, include finance, material, time, etc. While being resources, support also includes coaching and mentoring, feedback, etc. consultancy support can also be counted. Structural supports to be given to the employee, as stated above, include finance, material, time, etc. While being resources, support also includes coaching and mentoring, feedback, etc. consultancy support can also be counted. Kanter (1993) claims that in this process, the negative feelings of the employee stem from a lack of will or management over power. Kanter refers to the support of the employee's resources with organizational resources as structural support in the ways described above.

On the other hand, psychological empowerment refers to the process that develops through the interaction of the employee with her environment and has the perception that she has power in her environment (Zimmerman, 1995). The main emphasis is on the perception that the employee has this power at the end of the cognitive process internally (Conger \& Kanungo, 1988). Thomas and Velthouse claim that the perception of psychological empowerment is based on functions such as organizational empowerment, autonomy, and organizational climate. Researchers claim that when employees' psychological empowerment perceptions are high, their positive outcomes will also increase (Meng et al., 2016). Spreitzer (1995), who claims that the employee's perception of competence affects their assessment of whether they can perform the task well or not, states that the practices of the organization that will positively support or at least not prevent this perception are an important determinant. It is claimed that the supportive climate of the organization provides meaning for the work 
that the employee does, functions as an internal reward, plays a role in defining identity, and encourages them to be more productive by motivating them (O'Brien, 2010). Spreitzer (1995), who claims that the factor that increases the performance at the end of the process is the employee's making sense of it, defines the meaning as the level of caring about the employee's job. Another important result of the psychological empowerment process is that the employee perceives that he or she is autonomously making changes in the lives of others. It is thought that the employee who can meet the needs and demands of the service receiving party with his own resources and by acting autonomously will experience satisfaction. As a result, it is claimed that psychological empowerment consists of 4 subdimensions (Thomas \& Velthouse, 1990). It is claimed that individuals' perceptions of psychological empowerment will be formed through these titles called competence, meaning, self-determination and impact. Competence is defined as an individual's fulfillment of job responsibilities in accordance with expectations. An individual with a perception of competence thinks that his/her technical competence and individual abilities are sufficient. Meaning is defined as the individual's seeing his job as a part of his life and caring about his job (Spreitzer, 1995). Self-determination, on the other hand, is defined as the individual's perception of using willpower in his work and directing the process in the execution of the work. It is reported that employees with a high level of self-determination are able to make independent decisions and act autonomously (O'Brien, 2010). Being able to make an impact on others refers to the perception of creating a positive impact on others through the work that the individual has done. Seeing the positive results of the individual's contribution to others increases this perception. In addition to using the perception of psychological empowerment as a direct determinant in research, it can also be seen that it can be used as a mediator and regulator in many research models (Lina Meng, 2016). Generally, studies on health workers in the service sector report that psychological empowerment has negative effects on Burnout and can significantly reduce Burnout (Hochwalder, 2007).

Although the research is modelled within the framework of the conservation of resources theory, Karasek's Work Tension Theory also supports it. Karasek (1979) prepared a matrix in which she presented the results in different situations, taking into account the needs of the job and the autonomy that the employee can use while performing this job. According to this matrix, as can be seen in Figure 1 , the demands of the job can be high and low, and the employee's control over the work can be high and low. In this framework, the situation where the demands of the job and the control of the employee are high is called active, the situation where the demands of the job are low and the control of the employee is high is called low strain, the situation where the demands of the job are high and the control of the employee is low is called passive state, and the situation where the control of the employee is high is called high strain (Lévi et al., 2000). The model in which structural factors and social factors are taken into account can explain the Burnout mechanism in high demand business sectors (Hockwalder, 2007). Apart from Hockwalder (2007), who tested the validity of these results in his study on nurses, Laschinger, Finegan, and Shamian (2003) also observed that psychological empowerment negatively affected Burnout in a 3-year longitudinal study on nurses. Another result of the studies is that the support of colleagues and other employees is observed to be more effective than structural supports in the organization (Corsun \& Enz, 1999). 


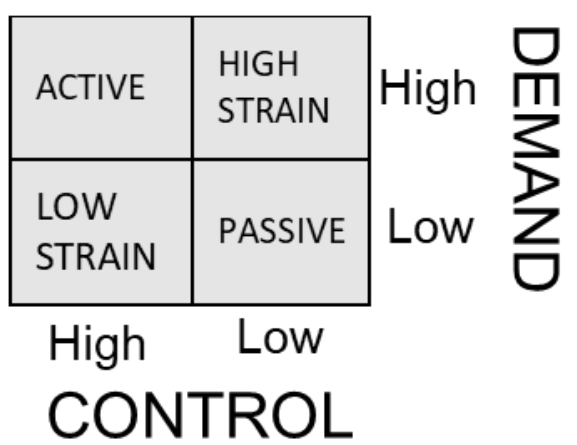

\section{Figure 1. Job Strain Model}

\section{Individualism and Collectivism}

Sociocultural factors affect individuals' perceptions and behaviors (Kasa \& Hassan, 2016). Within the framework of learning theories, individuals internalize the characteristics of the societies they were born and raised in and reflect them on their behaviors. Hofstede $(1980,1984)$, who has done one of the most comprehensive studies on the classification of cultures of societies in the world, defined cultures according to individual-collectivist, power distance, masculine-feminine, uncertainty avoidance, long and short future orientation dimensions. Based on the studies (Kirkman, Lowe, \& Gibson, 2006) revealing that these cultural characteristics of societies have a greater impact on behaviors than many factors, it is thought that perceptions of individualism and collectivism may have an impact on individuals' Burnout. Individualism, which is generally used to describe the individuals of western societies, defines the individual's ability to act independently of the society in which he lives by prioritizing his own wishes and needs (Kılınç, 2021). Collectivism, which is defined as the opposite of individualism, defines the state of being interdependent with the society in which the individual lives (Markus \& Kitayama, 1991). Individual desires and wishes are more valued in individual societies.

Considering the research model, it was thought that the perception of individualism and collectivism, which was seen as a direct independent variable, could actually play a completely independent role under certain conditions. Considering these conditions for this research, some of these conditions can be met in different business lines of the service sector, where employees will need many resources. It is thought that individuals who work in business lines directly related to the satisfaction perceptions of individuals such as nursing, bank clerk, accommodation sector, teaching will need many resources such as time, feedback, materials, finance. Obtaining many of the resources they will need or having control over resources requires employees to be dependent on other employees or to have a very high level of interaction. The characteristics of collectivist societies can be observed in organizations formed by employees who have to work interdependently. In this context, we are living in a period where the criticisms on teachers are increasing, where education is increasingly being questioned. In this process, teachers' efforts to provide the best education and training service they can by personalizing their professions and empathizing with the service recipient are related to the resources they have. It is thought that a teacher who has sufficient resources, namely time, financial resources, materials and feedback, can fulfill the responsibilities expected from him/her properly. On the contrary, if he cannot have these resources, also if he does not have the relations to obtain these resources, if he is in an organization that encourages individual culture, if only competition and individual success are at the forefront, we can think that the resources from which the teacher can ask for help and support are limited or not at all. If a teacher who works in an environment that embraces employees in an organization with collectivist cultural characteristics can reach the resources he needs by using collectivist networks, he can minimize the effects of stressors. However, the opposite is observed in cultures with individual characteristics. In these societies where individual success and personal wishes are considered important, other individuals in the organization are considered as competitors. In other 
words, a teacher trying to fulfill his responsibilities asking for help from his colleagues about the resources he will need is interpreted as asking for help from his opponent in an individual society. In other words, the experience that two teachers, who have the same conditions and work under the same conditions, one with a collectivist culture and the other with an individual culture, will gain in the process of providing the resources they will need is realized in this way. As a result, a teacher working in an individual culture is not expected to ask for help and support for the resources he will need, while he does not have any responsibility to the organization he is in for any subject other than his job responsibilities. However, a teacher with a collectivist culture may not only have job responsibilities but also feel responsibilities towards the organization in which he is involved, and in fact, may request the support and assistance of the organization in providing the resources he will need within the organization. In this way, it can minimize the effect of stressors. By reducing the effect of stressors, it can prevent chronic stress and Burnout as a result.

\section{Theoretical Background, Hypotheses and Research Model}

The relationship between sociocultural factors and Burnout can also be explained within the framework of the Conservation of Resources theory. Hobfoll (1989) claims that some of the resources that individuals value, such as self-esteem, self-confidence, social status, and position, are threatened by environmental factors. It is thought that the individual tends to protect these resources that he values and his satisfaction will increase as he protects these resources. Within the framework of the Conservation of Resources Theory, it is thought that teachers will need the emotional and physical resources they will need to carry out their daily lives in a healthy way when they are exposed to stress due to cultural and environmental factors. The reactions of teachers to these environmental and cultural sources of stress, which negatively affect their ordinary situations, can increase or protect their resources with the support of factors such as the social context in which they are consuming their resources. For example, it can be thought that a teacher who has to cope with a very high workload in a certain period of time will experience stress, lose time, energy and motivation. Within the framework of the theory, this situation can be considered as the loss of resources. In this process, it can be ensured that the teacher receives support from other colleagues to get the job done or protects his resources through factors such as institutional empowerment and psychological empowerment. In this respect, it was thought that psychological empowerment could be a regulatory variable independent of the independent variables Individualism and collectivism. In line with these assumptions, the model of the research was based on the Conservation of Resources theory. Again, as stated above, Karasek's Work Tension theory also supports the research model. In this context, the following hypotheses were formed.

\footnotetext{
$\mathrm{H}_{1}$ : Individualistic tendencies increase Burnout.

$\mathrm{H}_{2}$ : Collectivist tendencies reduce Burnout.

$\mathrm{H}_{3}$ : Psychological empowerment reduces the effect of individualistic tendencies on Burnout.

$\mathrm{H}_{4}$ : Psychological empowerment increases the effect of collectivist tendencies on Burnout.
} 


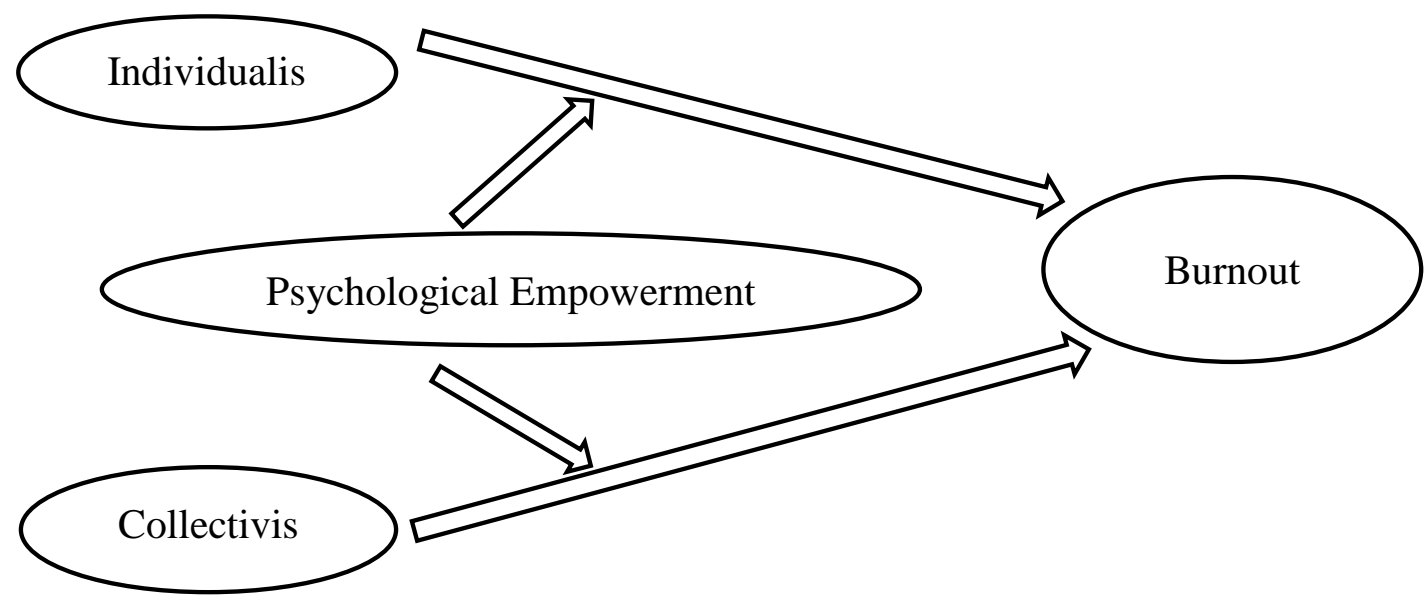

Figure 2. Research Model

\section{Model of the Research}

As can be seen from the model illustration given in figure 2 above, the moderator role that the perception of psychological empowerment has on effecting individualist and collectivist perceptions on the perception of Burnout was attempted to be presented via survey method involving a sample of teachers.

\section{Working group}

The study group of the research consisted of 207 teachers working in public secondary schools in Sinop. In the research, data was collected from approximately 400 teachers who were contacted faceto-face. After evaluation and sorting out, data from the remaining 207 questionnaires were processed. The questionnaires were distributed to all teachers who could be reached via simple random sampling. The completed and returned questionnaires were then evaluated. When examined, it was observed that some questionnaires had too many questions left unanswered, rendering them invalid.

When total number of teachers who filled out the questionnaire was compared with the number of assessable questionnaires versus the returned questionnaires, it was inferred that teachers were generally reluctant to answer questions regarding Burnout. The age, gender count and percentages of the participants are presented in Table 1.

Table 1. Age-Gender Crosstable

\begin{tabular}{llllll} 
& & \multicolumn{2}{l}{ Total } \\
\cline { 3 - 5 } & & & Female & Male & \\
\hline \multirow{2}{*}{ Age } & $\mathbf{1 8 - 2 5}$ & $\mathrm{N}$ & 36 & 24 & 60 \\
& $\mathbf{2 6 - 3 3}$ & $\mathrm{N}$ & 22 & 24 & 46 \\
& $\mathbf{3 4 - 4 1}$ & $\mathrm{N}$ & 24 & 30 & 54 \\
& $\mathbf{4 2 - 4 9}$ & $\mathrm{N}$ & 12 & 20 & 32 \\
& $\mathbf{5 0}$ and above & $\mathrm{N}$ & 6 & 9 & 15 \\
\hline Total & & $\mathrm{N}$ & 100 & 107 & 207
\end{tabular}


When Table 1 is examined, one third of the participants are teachers in the 18-25 age group (29\%). 15 participants are over the age of 50 and they constitute $7.2 \%$ of the total. Almost half of the participants are women (47.8\%). Male participants comprise $51.7 \%$ of the total.

\section{Measurement Scales:}

For the research, the 5-point Likert-type measurement scales presented below were used.

\section{Burnout Inventory}

The Maslach Exhaustion Inventory (MBI), developed by Maslach and Jackson (1981) and having undergone a validity and reliability study in Turkish conducted by Ergin (1992), was used in order to measure the perception of exhaustion which is the dependent variable used in the research. The MBI is a psychological assessment instrument and the following 22 items of the inventory were used: subdimensions of emotional exhaustion ( 9 items), personal achievement ( 8 items), and depersonalization (5 items). Items of the personal achievement scale (items 10-17) were reverse-scored in the scale. Some of the items in the scale are in the form of "I feel that I have come to the end of the road" and "I feel that the people I interact with as part of my job act as if I created some of their problems".

\section{Individual and Collectivist Perception Scale}

In order to measure the perception of individualism and collectivism which are independent variables used in the research, the Individual and Collectivist Perception scale developed by Xie et al (2006) and utilised in the Turkish literature by Özbek (2010), was used. The Indivudual and Collectivist Perception scale helps measure the two factors of individual tendencies ( 8 items) and collectivist tendencies ( 8 items), totalling 16 items. There is no reverse-scored item in the scale. Some of the items of the scale include "Happiness for me is spending time with others" and "It is important for me to do my job better than others".

\section{Psychological Empowerment Scale}

In order to measure the psychological empowerment variable tool, a 12-item psychological empowerment scale consisting of 4 dimensions (meaning, competence, autonomy and impact) developed by Spreitzer (1992) and validated and deemed reliable in Turkish by Altındiş and Özutku (2011), was used. There is no reverse-scored item in the scale. Some items of the scale include "The job I do is very important to me" and "I am confident that I have the capacity to perform the activities related to my job".

Table 2. Validity and Reliability of Measurement Tools

\begin{tabular}{llllllllll}
\hline Scale Name & $\begin{array}{l}\text { KMO } \\
\text { Test }\end{array}$ & Sig & $\begin{array}{l}\text { Reliability } \\
\text { (Cron.Alph } \\
\text { a) }\end{array}$ & $\begin{array}{l}\text { Tot. } \\
\text { Diff. } \\
\text { Ratio }\end{array}$ & $\begin{array}{l}\text { Facto } \\
\text { r }\end{array}$ & $\begin{array}{l}\text { Tot. } \\
\text { Expr. } \\
\text { Num. }\end{array}$ & $\begin{array}{l}\text { Normal } \\
\text { ity }\end{array}$ & $\begin{array}{l}\text { Skewnes } \\
\text { s }\end{array}$ & $\begin{array}{l}\text { Kurtosi } \\
\text { s }\end{array}$ \\
\hline Exhaustion & 0,817 & 0,000 & 0,894 & $\% 49$ & 3 & 22 &, 001 &, 405 &, 025 \\
Individualism & 0,847 & 0,000 & 0,806 & $\% 48$ & 1 & 8 &, 000 &, 347 &,- 401 \\
Collectivism & 0,857 & 0,000 & 0,824 & $\% 42$ & 1 & 8 &, 000 &,- 254 & .324 \\
$\begin{array}{l}\text { Psychological } \\
\text { Empowermet }\end{array}$ & 0,842 & 0,000 & 0,942 & $\% 55$ & 4 & 12 &, 000 &,- 529 &,- 534 \\
\hline
\end{tabular}

When the explanatory validity analysis results of the measurement tools used in the research were examined, it was observed that all were above the threshold value of 0.80 (Field et al., 2000) in the KMO 
KILINÇ \& YENER - Çukurova Üniversitesi Eğitim Fakültesi Dergisi, 50(2), 2021, 1100-1126

Barlett Sphericity test. It was observed that the variable of the 22-item Exhaustion scale had a disclosure rate of $49 \%$. It was mentioned that two sub-dimensions of the same scale were used to measure individualism and collectivism tendencies. It was revealed that both scales were higher than the KMO Barlett sphericity test threshold value. It was observed that the individualism scale had a disclosure rate of $48 \%$, and the collectivism scale had a disclosure rate of $42 \%$. It was observed that both scales comprised of 8 'single-factor' items. The KMO Barlett Sphericity result of the psychological empowerment scale was above the threshold value $(0.842)$, and the disclosure rate was noted as $55 \%$. In Table 2, the two sub-dimensions of the Individualism and Collectivism scale are considered as independent variables and evaluated separately as can be seen from the research model illustration. The confidence level of all scales were observed above the Cronbach Alpha threshold value of 0.70 .

\section{Data Collection and Analysis}

Data from the teachers who constituted the study group of the research was collected between October 2019 and January 2020.

When considering the results of the normality test applied before the analysis of the data, it can be stated that normality was not observed since all the variables turned out significant.

However, when the results of the kurtosis and skewness test used in the interpretation of the normal distribution test are examined in Table 2, it can be said that it is appropriate to apply parametric tests since all values are between the threshold values $(-1,500$ and +1500$)$.

\section{FINDINGS}

\section{Relationship between the variables}

The results of the Pearson correlation test, which is applied to reveal the level and direction of the relationship between the variables, are given in Table 3.

Table 3. Relationship Between The Variables

\begin{tabular}{llllll}
\hline & & $\begin{array}{l}\text { Psychological } \\
\text { Empowerment }\end{array}$ & Burn Out & Collectivism & Individualism \\
\hline $\begin{array}{llll}\text { Psychological } \\
\text { Empowerment }\end{array}$ & Pear.Cor. & 1 & & & \\
Burn Out & Pear.Cor. &,$- 369^{* *}$ & 1 & \\
Collectivism & Pear.Cor. &, $230^{* *}$ &,$- 342^{* *}$ & 1 & \\
Individualism & Pear.Cor. &,$- 213^{* *}$ &, $432^{* *}$ &,- 132 & 1 \\
\hline
\end{tabular}

** All correlations are significant, at least at $p<.01$ ( 2 tailed)

Pearson correlation test results between the variables are shown in Table 3. In line with the results; moderately and statically significant inverse relationship between psychological empowerment and Exhaustion ( $r=-.369, p<.01)$, moderately and statically significant inverse relationship between collectivism and burn out $(r=-, 369, p<, 01)$, and lastly moderately and statically significant inverse relationship between individualism and burn out $(r=-, 369, p<, 01)$ were revealed.

\section{Model Test}

Table 4. Research Model Summary

\begin{tabular}{lllllll}
\hline $\mathrm{R}$ & $\mathrm{R}^{2}$ & $\mathrm{MSE}$ & $\mathrm{F}$ & $\mathrm{Df1}$ & $\mathrm{Df2}$ & $\mathrm{P}$ \\
, 5694 &, 3242 &, 0930 & 32,4663 & 3,0000 & 203,0000 &, 000 \\
\hline
\end{tabular}


Table 5. Individualism - Burn Out - Psychological Empowerment Model Test

\begin{tabular}{lllllll}
\hline & $\beta$ & Std Error & $\mathrm{T}$ & $\mathrm{P}$ & $\mathrm{LLCl}$ & $\mathrm{ULCl}$ \\
Fixed &,- 0394 &, 0216 & $-1,8208$ &, 007 &,- 008 &, 0033 \\
Individualism &, 2994 &, 0571 & 5,2405 &, 0000 &, 1867 &, 4120 \\
$\begin{array}{l}\text { Psychological } \\
\text { Empowerment }\end{array}$ &,- 2345 &, 0463 & $-5,0650$ &, 0000 &,- 3258 &,- 1432 \\
Interaction &,- 4503 &, 1084 & $-4,1548$ &, 0000 &,- 6641 &,- 2366 \\
\hline
\end{tabular}

Interaction: Individualism vs. Psychological Empowerment

The data collected for testing the research model were defined in the IBM SPSS 22 and analyzed with a macro, called Process 3.0, which can be integrated into SPSS. When the test results, which are conducted toreveal the effect of individualism on Exhaustion and the role of the moderatorvariable of psychological empowerment in this relationship, are examined; it was observed that individualism significantly increased Exhaustion $(\beta=.30 ; P<0.01)$ and decreased psychological empowerment significantly $(\beta=-.23 ; P<0.01)$. The second test is conducted to reveal the effects of the interaction ofindividualism and psychological empowerment on Exhaustion. Results are shown thatthe positive effect of individualism (increasing Exhaustion) was transformed into a negative effect (the effect that reduces Exhaustion) with a high coefficient $(\beta=-.45 ; P<0.01)$. It has also been observed that psychological empowerment contributes to reducing Exhaustion at the level of $45 \%$ as a regulator. When the coefficient of determination is examined ( $R 2=.32, p<0.01)$; it is observed that $32 \%$ of the change on Exhaustion, which is the dependent variable, can be explained by the interaction of individualism and psychological empowerment.

Table 6. Collectivism - Burn Out - Psychological Empowerment Model Summary

\begin{tabular}{lllllll}
\hline$R$ & $R^{2}$ & MSE & $F$ & Df1 & Df2 & $P$ \\
, 4537 &, 2058 &, 1093 & 17,5353 & 3,0000 & 203,0000 &, 000 \\
\hline
\end{tabular}

Table 7. Collectivism - Burn Out - Psychological Empowerment Model Test

\begin{tabular}{lllllll}
\hline & $\beta$ & Std Error & $T$ & $P$ & LLCI & ULCI \\
Fixed &,- 0211 &, 0235 &,- 8952 &, 3718 &,- 0674 &, 0253 \\
Collectivism &,- 2801 &, 0680 & $-4,1202$ &, 0001 &,- 4141 &,- 1460 \\
Psychological &,- 2410 &, 0506 & $-4,7600$ &, 0000 &,- 3409 &,- 1412 \\
Empowerment & & & & & &, 2362 \\
Interaction &,- 0200 &, 1299 &,- 1536 &, 8780 &,- 2762 &, \\
\hline
\end{tabular}

Interaction: Collectivism vs. Psychological Empowerment

Considering the results of the test conducted to reveal the effect of collectivism on Exhaustion and the role of the moderator variable of psychological empowerment in this relationship; it was observed that collectivism significantly reduced Exhaustion $(\beta=-.28 ; P<0.01)$, while psychological empowerment significantly reduced it $(\beta=-.24 ; P<0.01)$. Considering the effect of the interaction of collectivism and psychological empowerment on Exhaustion, it was observed that collectivism continued its negative effect (effect reducing Exhaustion) with a low coefficient $(\beta=-.02 ; P>0.01)$, but this relationship was statically insignificant.While the moderator effect of psychological empowerment was observed between individualism and Exhaustion, no effect was found between collectivism and Exhaustion. Considering the hypotheses, the following results were observed. 
KILINÇ \& YENER - Çukurova Üniversitesi Eğitim Fakültesi Dergisi, 50(2), 2021, 1100-1126
$\mathbf{H}_{\mathbf{1}}$ : Individualistic tendencies increase Exhaustion. (SUPPORTED)
$\mathbf{H}_{\mathbf{2}}$ : $\quad$ Collectivist tendencies reduce Exhaustion. (SUPPORTED)
$\mathbf{H}_{3}$ : Psychological Empowerment reduces the effect of individualistic tendencies on Exhaustion. (SUPPORTED)
$\mathbf{H}_{4}$ : Psychological Empowerment increases the effect of collectivist tendencies on Exhaustion. (NOT SUPPORTED)

\section{Discussions \& Conclusions}

Remarkable results were observed in this study, in which the effect of individual and collectivist tendencies, modeled within the framework of the conservation of resources theory, on burnout and the regulatory role of psychological empowerment in this effect were questioned. It was observed that individual tendencies had a significant and enhancing effect on burnout, while collectivist tendencies had significant and reducing effects. On the other hand psychological empowerment only regulated the effect of individual tendencies on burnout. Although collectivist tendencies had a strong effect on burnout, it was observed that psychological empowerment did not play a regulatory role.

According to the study conducted by Kasa and Hassan (2006), in which they questioned the regulatory roles of collectivism and individualism on burnout, no effect was observed. In this respect, the findings of this study do not support Kasa and Hassan's research. Kasa and Hassan argue that the determinants of burnout which are not observed in the relationship, are the context of the job rather than sociocultural factors. However, as claimed in Hofstede's cultural taxonomy, the behaviors and perceptions of individuals are affected by the characteristics of the society they live in. Although individualism is defined in many studies within the framework of individual characteristics such as selfexpression and self-confidence in society, it can be seen that it has disadvantages when looking at individual societies. For instance, it is known that due to the predominance of personal interests in an individual society, help, support, feedback, etc. tolerance behaviors are more rare than in collectivist societies. Although collectivist societies are seen as societies where individual freedoms are less and dimensions such as courage and self-confidence are lower when compared to individual societies, a climate of preservation, protection and assistance brought by paternalism is also observed in collectivist socieities. In this respect, it was observed in this study that although psychological empowerment did not have a regulatory role in the effect of collectivism on burnout, collectivism had a sigificant reducing role on burnout.

Another finding that should be discussed is that although psychological empowerment plays a regulatory role in individual tendencies, it does not play a role in collectivist tendencies. In terms of the characteristics of collectivist culture, it has more paternal, embracing, protective and preserving functions. An individual living in a collectivist culture can find someone to turn to when he needs help. In such cultures, the people around the individual can sometimes take action without the need for help. Many functions of psychological empowerment already exist as the norm in the core of collectivist societies. In this respect, the effect of psychological empowerment may be pale against the influence of collectivist tendencies because it has a very similar emphasis. From the point of view of individualism, the individual with individual tendencies tries not to play in others' hands by seeing other individuals as potential competitors in the society they live in. In this respect, it can be thought that individuals who want their own well-being or who do not see themselves as competitors can have psychological empowerment. In these circumstances, psychological empowerment may have a more effective role. The regulatory role of psychological empowerment in the effect of individualism on burnout can be explained in this way.

In terms of future studies, it is predicted that burnout will become more widespread in our society where individualism spreads. Activities that will increase interdependence and cooperation within the organization and structural reinforcements can be presented as alternative strategies. In addition, serious studies are needed to establish a student, teacher and family triangle in schools or other 
KILINÇ \& YENER - Çukurova Üniversitesi Eğitim Fakültesi Dergisi, 50(2), 2021, 1100-1126

educational institutions. It should be emphasized that the responsibility of education is not only the responsibility of teachers. Considering that teachers interact with students after a certain age and only between certain hours of the day for educational purposes, the responsibility of the teacher remains limited. In addition, the continuation or support of the education given by the teacher at school should be provided by the family at home. In this way, the psychological pressure on the teacher can be reduced.

Considering the limitations of the research, it is a limitation of the research to be conducted in Sinop, where both individual and collectivist tendencies are observed. Considering only secondary school teachers is another limitation. Considering the measurement tools used, it can be seen as another limitation that there are several versions of each measurement tool and that the most common ones are used in these studies.

In this study, all rules within the scope of the "Directive on Scientific Research and Publication Ethics of Higher Education Institutions" were followed. None of the actions mentioned under the heading "Actions Contrary to Scientific Research and Publication Ethics", which is the second part of the directive, have been carried out. 


\section{Türkçe Sürümü}

\section{Giriş}

Bireylerde farklı nedenlerden kaynaklanan stresin rehabilite edilmemesinin sonucunda kronikleşmesi birçok rahatsızlığa neden olmakta ve tükenmişlik de bu rahatsızlıklardan biri olarak görülmektedir. Bireylere verilen hizmetin memnuniyet algısının ve hizmet sektörünün çalışanlar üzerindeki kronik baskısı alanyazına tükenmişlik sendromunu kazandırmıştır (Freudenberger, 1980). Başlangıçta sağlık sektöründeki danışmanlar ve hemşirelerde yoğun olarak gözlenen tükenmişlik sendromu çalışanların duygusal olarak iflas etmesi, hayatın hemen hemen birçok alanında umutsuzluğa kapılması, sinizm duygusuna sahip olması ve eskiden sahip olduğu yetenek ve becerileri konusunda gerilemesi gibi birçok belirtiyle gözlenebilmektedir (Maslach ve Jackson, 1981). Başlangıçta idealist ve hayat dolu bireyler olarak çalışmaya başlayan bireylerin bir süre sonra tükenmişliğe sürüklenmelerini boylamsal çalışmalarla gözlemleyen Freudenberger (1975) çalışanların iş çevresini, işin özelliklerini inceleyerek kronik stresi temel belirleyici olarak tanımlamıştır. Stres bireyin olağan durumunu olumsuz etkileyen faktörlere (Stresör) karşı bireyin fiziksel, duygusal ve diğer boyutlarla vermiş olduğu tepki olarak tanımlanmaktadır (Yener, 2016). Başlangıçta yapılan çalışmalarda tükenmişliği tecrübe eden çalışanların hizmet verdiği bireylere karşı empati duydukları, tedavi, beklenti ve isteklerini karşılamak için işin gerektirdiği sorumluluklardan daha fazlasını katmaya çalıştıkları ve dolayısıyla kurumsal kaynakların bu süreci destekleyemediği, yardım ve destek göremedikleri gözlenmiştir. Kendilerini işle özdeşleştiren bu çalışanların ihtiyaç duydukları birçok kaynağı (zaman, malzeme, geri besleme, finansman vb.) bulamaması işiyle özel yaşamının sınırlarını ayıramaması işlerinin oluşturduğu baskıyı sürekli hale getirmektedir. Freudenberger'den sonra Maslach ve Jackson'ın ölçme aracı geliştirme ve tükenmişlik algısını diğer hizmet sektörlerinde ölçme gayretleriyle tükenmişlik algısının alt boyutları olan duygusal tükenme, kişisel başarısızlık algısı ve duyarsızlaşmayla alanyazına kazandırılmıştır. Hizmet sektörünün önemli bir alanı olan eğitim sektöründe de öğretmenlerin tükenmişlik yaşayabileceklerini ortaya koyan çalışmalar yaygınlaşmaya başlamıştır (Wu, 2020). Bu çalışmalarda özellikle öğretmenlerin yüksek iş stresi nedeniyle tükenmişlik yaşayabilecekleri ve bunun akıl sağlıklarını olumsuz etkileyebileceği ortaya konulmaktadır. Öğretmenlerde tükenmişlik ve ilişkili rahatsızlıkların belirtileri arttıkça öğretmenlerin tükenmişliği üzerine yapılan çalışmalar da giderek artmaya başlamıştır (Barutçu ve Serinkan, 2013). Öğretmenler üzerine yapılan bu çalışmalarda ortaya çıkan bir diğer sonuç da öğretmenlerden beklentilerin her toplumda çok yüksek olmasından dolayı öğretmenlerin üzerindeki psikolojik baskının giderek artmasıdır. Küresel düzeydeki dönüşümlerin etkisini hisseden Türkiye'de de özellikle eğitim ve öğretim hayatında birçok baskı faktörü (stres kaynağı) baş göstermeye başlamıştır. Öğrencilerden beklentiler, çocukların ailevi imkanları ve yetiştirilme tarzlarındaki farklılıklar, toplumsal dejenerasyon söylemleri, sürekli değişen eğitim politika ve stratejileri öğretmenler üzerinde fazlasıyla baskı ve stres oluşturmaktadır. Araştırma ve gözlemlere bakıldığında olumsuz birçok örneğin belirleyenleri ele alındığında tükenmişlik sendromunun belirtileri öğretmenlerde de gözlenebilmektedir (Durak ve Seferoğlu, 2017).

Bireyin yaşadığı toplumun sosyokültürel özelliklerinin bireyin davranışları üzerindeki etkisi birçok çalışmada ortaya konulmaktadır (Yener ve Arslan, 2017; Kasa ve Hassan, 2016). Hofstede'in (1980, 1984) kültür taksonomisini alanyazına kazandırmasından sonra bireyin psikolojisi ve davranışlarının belirleyenleri üzerinde sosyokültürel faktörlerin etkisini tanımlama çalışmaları giderek artmıştır. Temel olarak güç mesafesi, erillik-dişillik, bireyselcilik-kolektivizm, duygu durum dengesi, risk alma ve muhafazakar davranma gibi boyutlarla kültürleri sınıflandıran Hofstede davranışları ve algıları çözümlemek için bize ipuçları sunmaktadır. Bu çerçevede tükenmişlik konulu çalışmaların daha çok bireysel kültürlerdeki hizmet sektöründe yapılması, bizdeki çalışmaların küreselleşmeden sonra yaygınlaşması (kolektivizm algısının dejenere olması) gibi faktörler bu çalışmanın çıkış fikrini oluşturmuştur. 
Hobfoll'un (1989) kaynakların korunumu kuramından yola çıkarak bireylerin yaşamını sürdürürken sahip olduğu kaynakları tehdit eden stresörlerle karşılaştığında içinde yaşadığı toplumun sosyokültürel fonksiyonlarını kullanarak kaynaklarını muhafaza edebileceği ya da sosyokültürel fonksiyonların olmamasından dolayı kaynaklarını tüketebileceği düşünülmüştür. Bunun yanında tükenmişliğin kronik stres nedeniyle bireylerin kaynaklarını tüketmesi sonucu yaşanmasından dolayı psikolojik güçlendirme sayesinde bireyin rehabilite olarak tükenmişliği yaşamayacağı ya da daha düşük düzeylerde yaşayabileceği düşünülmüştür. Öğretmenlerin kültürel normları, psikolojik güçlendirme ve tükenmişlik literatüründen elde edilen sonuçlar çerçevesinde bu çalışmada Kaynakların Korunumu Kuramı çerçevesinde psikolojik güçlendirmenin bireysel ve kollektivist eğilimlerin tükenmişlik üzerindeki etkisini düzenleyebileceği önerilmektedir.

\section{Tükenmişlik}

Alanyazında tükenmişlik kavramının tanımlamaları Freudenberger'in 1975 yılındaki uygulamalarının sonuçlarına dayandırılmaktadır (O’Brien, 2010). Bir uyuşturucu danışma kliniğinde gönüllü olarak çalışmaya başlayan bir grup idealist danışmanın bir süre sonra iş yaşamında yaşadıkları olumsuz değişimleri gözlemleyen Freudenberger tükenmişlik kavramını tanımlamıştır. Danışmanların göreve başladıktan bir süre sonra yaşadıkları kronik başağrıları, bağırsak ve sindirim problemleri, hastalara olumsuz davranışları, özsaygı ve özgüven düşüklüğü gibi rahatsızlıklarını tanımlamaya çalışan Freudenberger gözlemlerini raporlaştırmıştır. Araştırmacı yukarıda bahsedilen uyuşturucu kliniğinde danışmanlık görevi gibi bir başkasının iyileşmesi veya iyiliği için çalışan ve kendisini adayan çalışanların stres yaşadıklarını ve bu stresin kronik hale gelmesiyle tükenmişlik yaşadıklarını belirtmiştir. Daha sonra Cherniss'in çalışmalarıyla tükenmişlik kavramının hizmet sektöründe birçok iş kolunda geçerliliğinin test edildiği görülmüştür (Cherniss, 1980). Cherniss'de (1980) aynı Freudenberger gibi başlangıçta idealist ve olumlu duygulara sahip hizmet sektörü çalışanlarının bir süre sonra olumsuz duygulara sahip olduğunu sinizmi tecrübe ettiğini, duyarsızlaştıklarını ve göreve ilgilerini kaybettiklerini gözlemlemiştir. Cherniss'in çalışmalarında öne çıkan diğer sonuç kamu ve kurumsallaşmış işletmelerde hizmet çalışanlarının özerkliklerinin olmamasının, maaşlarının standart olmasının bu stresi arttırmasıdır. Çalışanın kişisel özelliklerinin işe bakış ya da değerlendirme süreçlerini etkilediğini iddia eden Freudenberger'in (1975) çalışmalarının yanında Cherniss (1980) çalışanın özerkliği ve iş üzerindeki kontrolü gibi örgütsel faktörlerin de tükenmişlik üzerinde etkili olabileceğini iddia etmiştir. Cherniss (1980) hizmet çalışanlarının görevlerinin oluşturmuş olduğu baskıyı azaltmak için ihtiyaç duyacakları özerkliğin düzenleyici bir fonksiyon olabileceğini iddia etmektedir.

Tükenmişlik algısını ölçmek için alanyazında çok yaygın kullanılan ölçeğin sahibi Maslach ve Jackson (1981) tükenmişliği, çalışanın duygularını yoğun olarak kullandığı sektörlerde uzun dönem boyunca maruz kaldığı kronik iş kaynaklı stres sonucu yaşamış olduğu deneyim olarak tanımlamaktadır. Bu süreçte çalışanın fiziksel ve duygusal olarak yıprandığı, görevi gereği diğerlerinin iyiliğini düşünme sorumluluğundan dolayı gerginleştiği ve artan taleplere cevap veremediği, işe yönelik inanç, istek ve ideallerini kaybettiği raporlanmıştır (Demerouti, Mostert ve Bakker, 2010). Hizmet sektörü çalışanlarının yukarıda anlatılan koşullarda hizmet alan bireylere karşı sorumluluklarının yanında kurumsal kaynaklarının yetersiz olması durumunda, işe yönelik yönetim yetkilerinin olmaması durumunda, ödüllendirilmediklerinde ya da emeklerinin karşılığını alamadığı durumlarda umutsuzluğa ve yılgınlığa itilmektedirler (Yener ve Arslan, 2017). Süreç duygu odaklı görülse de Maslach tükenmiş çalışanların fiziksel rahatsızlığı da yaşayacaklarını iddia etmiştir. Sürekli nezle ve grip olma, kas-iskelet sistemi rahatsızlıkları, mide rahatsızlıkları, hipertansiyon, uyku bozuklukları gibi fiziksel rahatsızlıkların da tükenmişliğin olası sonuçları arasında olabileceği iddia edilmiştir (Maslach, 2003).

Örgütler açısından bakıldığında çalışanlarının bir süre sonra tükenmişlik belirtileri göstererek işe yabancılaşmaları, duyarsızlaşmaları, sinizm duygusuna sahip olmaları, performanslarının düşmesi kaçınılmaz olmaktadır. Çalışanların bu deneyimleri yaşamalarıyla fırsat bulduklarında işten ayrılmaları, sağlık nedeniyle uzun süreler işten uzak kalmaları, fiziken bulunsa da zihinsel olarak soyutlanmaları diğer dolaylı sonuçlarıdır. Maslach'ın tükenmişlik algısını ölçmek için yapmış olduğu çalışmalar sonucunda tükenmişliğin duygusal tükenme, duyarsızlaşma ve kişisel başarısızlık olarak adlandırdığı 3 bileşenli bir 
yapıdan oluştuğunu önermiştir. Duygusal tükenme bireyin duygusal kaynaklarının tamamen tükendiğini hissetmesiyle oluşmaktadır. Bu aşamada bireyin fiziksel, duygusal ve zihinsel tükenmişlik belirtileri göstermesi yaygındır. Bireyin herhangi bir şey yapmak için kendinde yeterli enerji ve isteği bulamaması belirtilerden birisidir. Yeme alışkanlığının bozulması, kronik başağrıları, bağırsak ve sindirim bozukları diğer belirtilerdir. İş yaşamında umutsuzluk, çaresizlik, beklentilerin kaybolması ve herşeyin düzeleceğine ilişkin inanışın tamamen yok olması yaygın görülen belirtilerdir (O’Brien, 2010). Umutsuz ve yardıma muhtaç bir şekilde kişinin kendi bağlamında tıkılıp kalması, diğerlerinin beklentilerine karşılık verememesi Maslach tarafından soğuk boş kabuk (cold empty Shell) olarak adlandırılmaktadır. Bu aşamada sinirlilik, gerginlik, depresyon, madde kullanımı, intihar eğilimlerinin yaşanabileceği iddia edilmektedir (Maslach, 2003). Tükenmişliğin son aşamasında bireylerin özyeterlilik ve başarı algılarında düşüş yaşanmaktadır. Hizmet sektöründeki çalışanlar bu aşamada hizmet verdikleri bireylerin beklentilerini karşılama düzeyinde yetersizlik algısına kapılmaktadırlar. Mesleki yeterlilikleri konusunda ikileme düşen tükenmiş çalışanlar karar vermekte zorlanarak genelde başarısız olmaktadırlar. Bu aşamada birey sadece iş yaşamında değil diğer yaşam alanlarında da özgüven ve özsaygı yetersizliği hissedebilmektedir.

Gözlemlere bakıldığında başlangıçta Freudenberger (1975) tarafından hizmet sektörü içinde yer alan sağlık sektöründe gözlenen belirtiler sonraki yıllardaki çalışmalarda bankacılık, öğretmenlik gibi insanlarla içiçe olan farklı hizmet sektöründeki iş kollarında da gözlenmiştir. Sektörün özelliklerinden kaynaklanan faktörlerin yani hizmet verilen kesimin insan olması, çalışanın vereceği hizmet ile problemlerine veya ihtiyaçlarına çözüm beklemesi gibi faktörler bu sektörleri diğer sektörlerden ayrıştırmaktadır. İnsanoğlunun tabiatından kaynaklanan bazı temel özellikler olan vicdan, şefkat vb. özellikler (Neff, 2011) çalışanın karşı tarafın yerine kendisini koymasına neden olmaktadır. Hizmet alan tarafın yerine kendisini koyan çalışanın işin, örgütün ve diğer faktörlerin etkisiyle beklentilerini karşılayamadığını düşünmesinin oluşturacağı stres ve bu stresin kronik hale gelmesi sonucu tükenmişliğin oluşacağı iddia edilmektedir (Freudenberger, 1975). Süreci tetikleyen belirleyenin stres olduğu dikkate alınırsa stresin tanımlanmasına gerek duyulmaktadır. Bireylerin olağan şartlarını etkileyen ve yaşantılarını değiştirmelerine neden olan faktörlere karşı bireylerin vermiş olduğu tepkiler stres olarak tanımlanmaktadır (Eren, 1998). Bireyin olağan yaşantısını etkilemesi için stresör olarak adlandırılan başlatıcı faktörün bireyin sahip olduğu kaynaklardan daha fazlasını bireyden talep etmesi gerekmektedir (Baltaş ve Baltaş, 1987). Örnek vermek gerekirse sabah 08:00'de işyerinde olması gereken bir bekar annenin çocuğunu saat 09:00'da muayeneye götürmek zorunda olması bir stresör etkisi oluşturabilir. Annen ücretli bir çalışan ise zamansal kaynakları bu durumu tek başına çözmesine imkan sağlamayabilir. Dolayısıyla annenin ya çocuğunu bir akrabası yoluyla muayeneye göndermesi ya da işvereninden izin alması gerekecektir. Uygun olan herhangi bir akrabasının olmaması annenin bu yönde ağ kaynaklarının da bu problemi çözmesine izin vermemesi durumudur. İşverenin izin vermemesi annenin zaman ve işe yönelik kaynaklardan da yoksun olduğunu göstermektedir. Tersi durumda annenin tek başına çözmesinin zor olduğu bu durumda anlayışlı bir işverenin annenin bu durumuna hoşgörü göstererek çocuğun tedavi sürecinde izin verebilmesi annenin stresöre yok edici bir tepki vermesini yani stresin oluşmasını engellemesini ifade etmektedir. Bu örnek üzerinden hareket edilirse annenin sadece çocuğunun muayene problemi değil birçok probleminde ihtiyaç duyacağı kaynaklara sahip olmaması bir süre sonra stresörlerin stresi oluşturmasına bunun sürekli hal alması ise stresin kronik hale gelmesine neden olmaktadır.

Bireylerin yaşamlarında değişiklik yapmasına neden olan stresör adı verilen faktörler birçok araştırmada ele alınmış hatta Thomas Holmes ve Richard Rahe bir stres envanteri geliştirmiştir. Bootzin ve Loftus (1983) bu envantere vurgu yaparak bireylerin yaşamlarında stresör etkisi yaratan faktörleri puanlamıştır. Bu puanlama sonucunda 0 ile 100 puan arasında puan verilen çeşitli faktörlere örnek vermek gerekirse işten ayrılma faktörü 50 puan olarak değerlendirilmiştir. İş dizaynı ya da iş çevresinin değiştirilmesi 39 puan, iş sorumluluğu değişimi 29 puan, amirle ilgili olan faktörler 23 puan olarak değerlendirilmiştir. Stres indeksinde 150-200 puan düzeyinde bireyin bireysel özelliklerinin de yani psikolojik dayanıklılık vb. özelliklerinin de etkisiyle stresin kronik hale gelmesi gözlenirken stresörlerin bireyde 300 puanlık bir etki yaptığında bireyin psikolojik rahatsızlık yaşadığı iddia edilmektedir (Bootzin 
ve Loftus, 1983). Stres envanterinde işe yönelik faktörlerin 187 puan gibi yüksek bir puana sahip olduğu görülmektedir. Bu durum işe yönelik faktörlerin bireylerin yaşamlarında kuvvetli bir stres belirleyicisi olabileceğini göstermektedir. Bu açıdan bireyin yaşamında stresin etkisini en aza indirmek amaçlandığında işe yönelik belirleyenlerin irdelenmesine gerek duyulabilir. İşe yönelik belirleyenlerin bireye yönelik etkisini olumlu hale getirecek stratejiler giderek alanyazında daha fazla araştırılmaktadır. Örgüt çerçevesinde liderliği, yapısal faktörleri, çalışma arkadaşlarını konu alan araştırmalar yaygınlaşmaktadır. Lider üye etkileşimi, destek, yapısal ve psikolojik güçlendirme gibi konu başlıkları bunlara örnek gösterilebilir. Bu çalışmada da öğretmenlerin tükenmişlik algıları üzerinde bireysel ve kolektivist eğilimlerin etkisi ve bu ilişki sürecinde psikolojik güçlendirmenin düzenleyici rolü araştırılmıştır.

\section{Psikolojik Güçlendirme}

Güçlendirme çalışanların karar alma süreçlerinde yer alması, kaynaklara erişiminin kolaylaştırılması, yetenek ve becerilerinin geliştirilmesi yönündeki desteği ifade etmektedir (Conger ve Kanungo, 1988). Güçlendirme alanyazında yapısal güçlendirme ve psikolojik güçlendirme olarak iki başlık altında incelenmektedir.

Yapısal güçlendirme Kanter'in Örgütlerde Yapısal Güç kuramına dayanmaktadır (Kanter, 1993). Kuram örgütlerde resmi veya resmi olmayan güç kaynaklarını örgütsel yapıları oluşturarak personelin güçlendirmesinde rol oynayabileceğini önermektedir. Örgütlerin çalışanların karar alma süreçlerine katıııııı, bireysel ve mesleki açıdan gelişimini teşvik eden, kariyer gelişiminin oluşumunu sağlayan yapıları yapısal güçlendirme araçlarına örnek olarak gösterilebilir. Örgüt içinde kaynakların üzerinde irade sahibi olan ve güç olarak tanımlanan belirleyenlerin çalışanlarca paylaşılması bilgiye ulaşım, destek ve diğer kaynaklara ulaşımının kolaylaştıııması süreci tanımlamaktadır. Çalışanların sorumluluklarını yerine getirmesi için ihtiyaç duyacakları kaynaklara erişimlerinin olması kaynak yoksunluğunu stresör olmaktan çıkarmaktadır. Finansal kaynak, malzeme, çalışma ortamının şartları, zaman vd. faktörler bu kaynaklara örnek olabilir. Çalışanların özellikle hizmet sektörü çalışanlarının muhatapları insan olduğu için sürece sadece örgütsel kaynakları değil aynı zamanda bireysel kaynakları da kattıkları düşünülmektedir. Çalışanın muhatabı olan hizmet talep eden tarafın isteklerini veya ihtiyacını karşılamak için empati kurduğu, vicdani yönden sorumluluk hissettiği ve elindeki bütün kaynaklarla yöneldiği varsayılmaktadır. Çalışanın tek başına elindeki kaynaklarla hizmet alan tarafın istek ve ihtiyacını karşılayamaması durumunda yaşayacağı olumsuz süreç yapısal destekle aşılabilir. Çalışana verilecek yapısal destekler yukarıda da ifade edildiği üzere finansman, malzeme, zaman, vd. kaynaklar olurken destek kapsamında aynı zamanda koçluk ve mentorluk, geri besleme vb. danışmanlık destekleri de sayılabilir. Çalışanın kaynaklar üzerinde irade sahibi olabildiği, karar alma mekanizmasında yer alabildiği, geri besleme vb. danışmanlık yardımı alabildiği bir örgütte özerkliğe sahip olabildiği düşünülebilir. Kanter (1993) bu süreçte çalışanın olumsuz duygularının güç üzerindeki irade ya da yönetim eksikliğinden kaynaklandığını iddia etmektedir. Kanter yukarıda anlatılan yollarla örgüt kaynaklarıyla çalışanın kaynaklarının desteklenmesini yapısal destekleme olarak adlandırmaktadır.

Psikolojik güçlendirme ise çalışanın çevresiyle etkileşimi süreciyle gelişen ve içsel olarak çevresinde güç sahibi olduğu algısına sahip süreci ifade etmektedir (Zimmerman, 1995). Çalışanın içsel olarak bilişsel süreci sonunda bu güce sahip olduğunu algılaması temel vurgudur (Conger ve Kanungo, 1988). Thomas ve Velthouse psikolojik güçlendirme algısının örgütsel güçlendirme, özerklik ve örgütsel iklim gibi fonksiyonlara dayandığıı iddia etmektedir. Araştırmacılar çalışanların psikolojik güçlendirme algılarının yüksek olduğu durumlarda olumlu çıktılarının da yükseleceğini iddia etmektedir (Meng vd., 2016). Çalışanın yetkinlik algısının görevi iyi yapıp yapamadığı konusundaki değerlendirmelerini etkilediğini iddia eden Spreitzer (1995) örgütün bu algıyı olumlu yönde destekleyecek veya en azından engel olmayacak uygulamalarının önemli bir belirleyici olduğunu ifade etmektedir. Örgütün destekleyici ikliminin çalışanda yaptığı işe yönelik anlam oluşmasını sağladığı, içsel ödül olarak fonksiyon oynadığı, kimlik tanımlamasında rol oynadığı, onları motive ederek daha verimli olmalarını teşvik ettiği iddia edilmektedir (O’Brien, 2010). Süreç sonunda performansın artmasını sağlayan faktörün çalışanın anlam çıkarması olduğunu iddia eden Spreitzer (1995) anlamı ise çalışanın işini umursama düzeyi olarak 
tanımlamaktadır. Psikolojik güçlendirme sürecinde oluşan bir diğer önemli sonuç ise çalışanın özerk bir şekilde diğerlerinin hayatında değişiklik yaptığını algılamasıdır. Karşısındaki hizmet alan tarafın ihtiyaç ve isteklerini kendi kaynaklarıyla ve otonom davranarak karşılayabilen çalışanın tatmin yaşayabileceği düşünülmektedir. Sonuç olarak yukarıda anlatılanlar ışı̆̆ında psikolojik güçlendirmenin 4 alt boyuttan oluştuğu iddia edilmektedir (Thomas ve Velthouse, 1990). Yetkinlik, anlam, öz belirleme ve etki olarak adlandırılan bu başıklar yoluyla bireylerin psikolojik güçlendirme algılarının oluşacağı iddia edilmektedir. Yetkinlik bireyin işe ilişkin sorumluluklarını beklentilere uygun olarak yapması olarak tanımlanmaktadır. Yetkinlik algısına sahip birey işe ilişkin teknik yeterlilik ve bireysel yeteneklerinin yeterli olduğunu düşünmektedir. Anlam bireyin işini yaşamının bir parçası olarak görmesi, işini önemsemesi olarak tanımlanmaktadır (Spreitzer, 1995). Öz belirleme ise bireyin işindeki irade kullanabilme, işin yürütülmesinde süreci yönlendirebilme algısı olarak tanımlanmaktadır. Öz belirleme düzeyi yüksek olan çalışanların bağımsız karar alabilme ve otonom davranabilme davranışını gösterebildikleri raporlanmaktadır (O’Brien, 2010). Diğerleri üzerinde etki oluşturabilmek ise bireyin yapmış olduğu iş yoluyla diğerleri üzerinde olumlu etki oluşturabilme algısını ifade etmektedir. Bireyin diğerlerine yaptığı katkının olumlu sonuçlarını görmesi bu algıyı arttırmaktadır. Araştırmalarda psikolojik güçlendirme algısının doğrudan belirleyici olarak kullanılmasının yanında birçok araştırma modelinde aracı ve düzenleyici olarak kullanılabildiğini de görebilmektedir (Lina Meng, 2016). Genellikle hizmet sektöründe sağlık çalışanları üzerine yapılan çalışmalarda psikolojik güçlendirmenin tükenmişlik üzerinde olumsuz etkileri olduğu tükenmişliği anlamlı bir şekilde düşürebildiği de araştırmalarda raporlanmaktadır (Hochwalder, 2007).

Araştırma kaynakların korunumu kuramı çerçevesinde modellenmesine rağmen Karasek'in İş Gerilim Kuramı da desteklemektedir. Karasek (1979) işleri tanımlarken işin oluşturduğu gereksinimleri ve çalışanın bu işi icra ederken kullanabildiği otonomiyi dikkate alarak farklı durumlardaki sonuçları sunduğu bir matris hazırlamıştır. Bu matrise göre şekil 1' de de görüldüğü üzere işin talepleri yüksek ve düşük, çalışanın iş üzerindeki kontrolü yüksek ve düşük olabilir. Bu çerçevede işin taleplerinin ve çalışanın kontrolünün yüksek olduğu durum aktif olarak, işin taleplerinin düşük çalışanın kontrolünün yüksek olduğu durum düşük gerilim, işin taleplerinin yüksek çalışanın kontrolünün düşük olduğu durum pasif durum, işin taleplerinin yüksek çalışanın kontrolünün düşük olduğu durum ise yüksek gerilim olarak adlandırılmaktadır (Lévi, Bartley, ve Landsbergis, 2000). Yapısal faktörler, sosyal faktörlerin dikkate alındığı model yüksek talebe sahip iş sektörlerinde tükenmişlik mekanizmasını açıklayabilmektedir (Hockwalder, 2007). Hemşireler üzerinde yaptığı çalışmada bu sonuçların geçerliliğini test eden Hockwalder'in (2007) dışında Laschinger, Finegan ve Shamian'ın (2003) yine hemşireler üzerinde yaptığı 3 yılı kapsayan boylamsal çalışmada psikolojik güçlendirmenin tükenmişliği olumsuz etkilediği gözlenmiştir. Çalışmalarda ortaya çıkan bir diğer sonuç iş arkadaşları ve diğer çalışanların desteğinin örgütte yapısal desteklerden daha fazla etkili olarak gözlemlenmesidir (Corsun ve Enz, 1999).

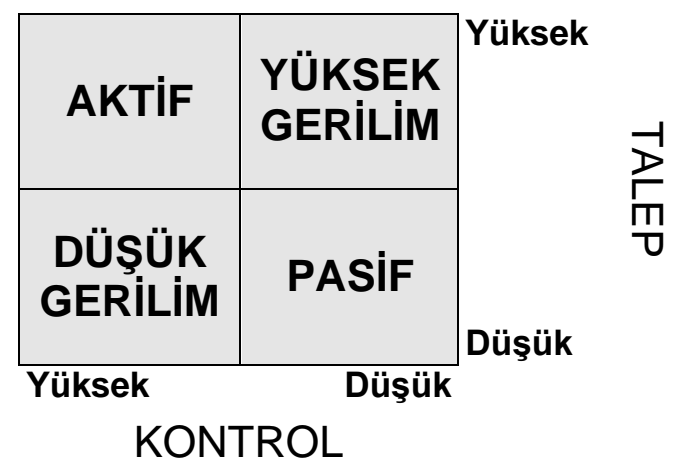

Şekil 1. İ̧̧ Gerilim Modeli

Bireyselcilik ve Kolektivizm 
Sosyokültürel faktörler bireylerin algılarını ve davranışlarını etkilemektedir (Kasa ve Hassan, 2016). Öğrenme kuramları çerçevesinde bireyler doğup büyüdükleri toplumların özelliklerini içselleştirerek davranışlarına yansıtırlar. Dünyada toplumların kültürlerinin sınıflandırılmasına ilişkin en kapsamlı çalışmalardan birisini yapmış olan Hofstede $(1980,1984)$ kültürleri bireysel-kolektivist, güç mesafesi, erkeksi-kadınsı, belirsizlikten kaçınma, uzun ve kısa geleceğe yönelme boyutlarına göre tanımlamıştır. Toplumların bu kültürel özelliklerinin davranışlar üzerinde birçok faktöre göre daha fazla etkiye sahip olduğunu ortaya koyan çalışmalardan (Kirkman, Lowe ve Gibson, 2006) hareketle bireyselcilik ve kolektivizm algılarının bireylerin tükenmişlikleri üzerinde etkili olabileceği düşünülmektedir. Genellikle batılı toplumların bireylerini tanımlamak için kullanılan bireyselcilik bireyin kendi istek ve ihtiyaçlarını öncelikleyerek, içinde yaşadığı toplumdan bağımsız davranabilmesini tanımlamaktadır (Kılınç, 2021). Bireyselciliğin zıddı olarak tanımlanan kolektivizm ise bireyin içinde yaşadığı toplumla karşılıklı bağımlı olma durumunu tanımlamaktadır (Markus ve Kitayama, 1991). Bireysel arzu ve istekler bireysel toplumlarda daha fazla değer görmektedir.

Araştırma modeline bakıldığında doğrudan bir bağımsız değişken gibi görülen bireyselcilik ve kolektivizm algısının aslında belirli şartlarda tam bir bağımsız rol oynayabileceği düşünülmüştür. Bu araştırma için bu şartlar dikkate alındığında çalışanların birçok kaynağa ihtiyaç duyacağı hizmet sektörünün farklı iş kollarında bu şartların bir kısmı sağlanabilir. Hemşirelik, banka memurluğu, konaklama sektörü, öğretmenlik gibi doğrudan bireylerin memnuniyet algılarına yönelik iş kollarında çalışanlar bireylerin zaman, geri besleme, malzeme, finansman gibi birçok kaynağa ihtiyaç duyacakları düşünülmektedir. İhtiyaç duyacakları birçok kaynağı elde etmek ya da kaynaklar üzerinde kontrol yetkisine sahip olmak çalışanların diğer çalışanlarla bağımlı çalışmasına yada çok yüksek bir etkileşim düzeyine sahip olmasını gerektirmektedir. Birbirleriyle bağımlı çalışmak zorunda kalan çalışanların oluşturduğu örgütlerde kolektivist toplumların özellikleri gözlenebilir. Bu çerçevede eğitimin giderek sorgulandığı günümüzde öğretmenler üzerindeki eleştirilerin arttığı bir dönemi yaşamaktayız. Bu süreçte öğretmenlerin beklentileri karşılamak için mesleklerini kişiselleştirerek, hizmet alan tarafla empati kurarak elinden gelen en iyi eğitim ve öğretim hizmetini verme gayreti sahip olduğu kaynaklarla ilişkilidir. Yeterli kaynağa yani zamana, finansal kaynaklara, malzemeye, geri beslemeye sahip olan bir öğretmenin kendisinden beklenen sorumlulukları hakkıyla yerine getirebileceği düşünülmektedir. Bunun tersi durumda bu kaynaklara sahip olamadığı durumda şayet bu kaynakları elde edebileceği ilişkilere de sahip değilse, bireysel kültürü teşvik eden bir örgütte bulunuyorsa, salt rekabet ve bireysel başarı ön plandaysa öğretmenin yardım ve destek isteyebileceği kaynakların da sınırlı ya da hiç olmadığını düşünebiliriz. Kolektivist kültür özelliklerine sahip bir örgütte çalışanları kucaklayıcı bir ortamda görev yapan bir öğretmen ihtiyaç duyduğu kaynaklara kolektivist ağlarını kullanarak ulaşabiliyorsa stresörlerin etkisini en aza indirebilir. Oysa bu durum bireysel özelliklere sahip kültürlerde tam tersi gözlenmektedir. Bireysel başarı ve kişisel isteklerin önemsendiği bu toplumlarda örgüt içindeki diğer bireyler rakip olarak değerlendirilmektedir. Yani sorumluluklarını yerine getirmeye çalışan bir öğretmenin ihtiyaç duyacağı kaynaklar konusunda iş arkadaşlarından yardım istemesi bireysel bir toplumda rakibinden yardım istemesi olarak anlamlandııımaktadır. Yani aynı şartlara sahip, aynı koşullarda görev yapan biri kolektivist kültüre sahip diğeri bireysel kültüre sahip iki öğretmenin ihtiyaç duyacağı kaynakları temin etme sürecinde edinecekleri deneyim bu şekilde gerçekleşmektedir. Sonuç olarak bireysel kültürde çalışan bir öğretmenin iş sorumlulukları dışında herhangi bir konu için içinde bulunduğu örgüte karşı sorumluluğu bulunmazken intiyaç duyacağı kaynaklar konusunda da yardım ve destek talebinde bulunması beklenmemektedir. Oysa kolektivist kültür özelliklerine sahip bir öğretmen sadece iş sorumlulukları değil birçok konuda içinde bulunduğu örgüte karşı sorumluluk hissederken aslında örgüt içinde intiyaç duyacağı kaynakları temin etmede de örgütün destek ve yardımını talep edebilir. Bu sayede stresörlerin etkisini en aza indirebilir. Stresörlerin etkisini indirerek kronik stresin ve sonucunda tükenmişliğin yaşanmasını engelleyebilir. 


\section{Kuramsal Altyapı, Hipotezler ve Araştırma Modeli}

Sosyokültürel faktörler ve tükenmişlik arasındaki ilişki Kaynakların Korunumu kuramı çerçevesinde de açıklanabilir. Hobfoll (1989) bireylerin değer verdiği özsaygı, kendine güven, sosyal statü, pozisyon gibi bazı kaynaklarının çevresel faktörler tarafından tehdit edildiğini iddia etmektedir. Bireyin değer verdiği bu kaynakları koruma eğiliminde olduğu ve bu kaynaklarını korudukça memnuniyetinin artacağı düşünülmektedir. Kaynakların Korunumu Kuramı çerçevesinde öğretmenlerin kültürel ve çevresel faktörlerden dolayı strese maruz kaldıklarında günlük yaşamlarını sağlıklı bir şekilde yürütmek için ihtiyaç duyacağı duygusal ve fiziksel kaynaklara ihtiyaç duyacakları düşünülmektedir. Öğretmenlerin olağan durumlarını olumsuz etkileyen çevresel ve kültürel kaynaklı bu stres kaynaklarına vermiş oldukları tepkiler kaynaklarını tüketirken içinde bulunduğu sosyal bağlam gibi faktörlerin desteğiyle kaynaklarını arttırabilir ya da koruyabilir. Örnek vermek gerekirse belirli bir zaman diliminde çok yüksek bir iş yükünün altından kalkmak zorunda olan bir öğretmenin stres yaşayacağı, zamanını, enerjisini, motivasyonunu kaybedebileceği düşünülebilir. Kuram çerçevesinde bu durum kaynakların kayboluşu olarak düşünülebilir. Bu süreçte öğretmenin diğer çalışma arkadaşlarından işin yapılması için destek görmesi veya kurumsal güçlendirme, psikolojik güçlendirme gibi faktörler aracılığıyla kaynaklarını koruması sağlanabilir. Bu açıdan psikolojik güçlendirmenin bağımsız değişkenler olan Bireyselcilik ve kolektivizim algılarından bağımsız olarak düzenleyici değişken olabileceği düşünülmüştür. Bu varsayımlar doğrultusunda araştırmanın modeli Kaynakların Korunumu kuramına oturtulmuştur. Yine yukarıda da ifade edildiği gibi Karasek'in İş Gerilim kuramı da araştırma modelini desteklemektedir. Bu çerçevede aşağıdaki hipotezler oluşturulmuştur.
$\mathrm{H}_{1}$ : Bireyselci eğilimler tükenmişliği arttırmaktadır.
$\mathrm{H}_{2}$ : Kolektivist eğilimler tükenmişliği azaltmaktadır.
$\mathrm{H}_{3}$ : Psikolojik güçlendirme bireyselci eğilimlerin tükenmişlik üzerindeki etkisini azaltmaktadır.
$\mathrm{H}_{4}$ : Psikolojik güçlendirme kolektivist eğilimlerin tükenmişlik üzerindeki etkisini arttırmaktadır.

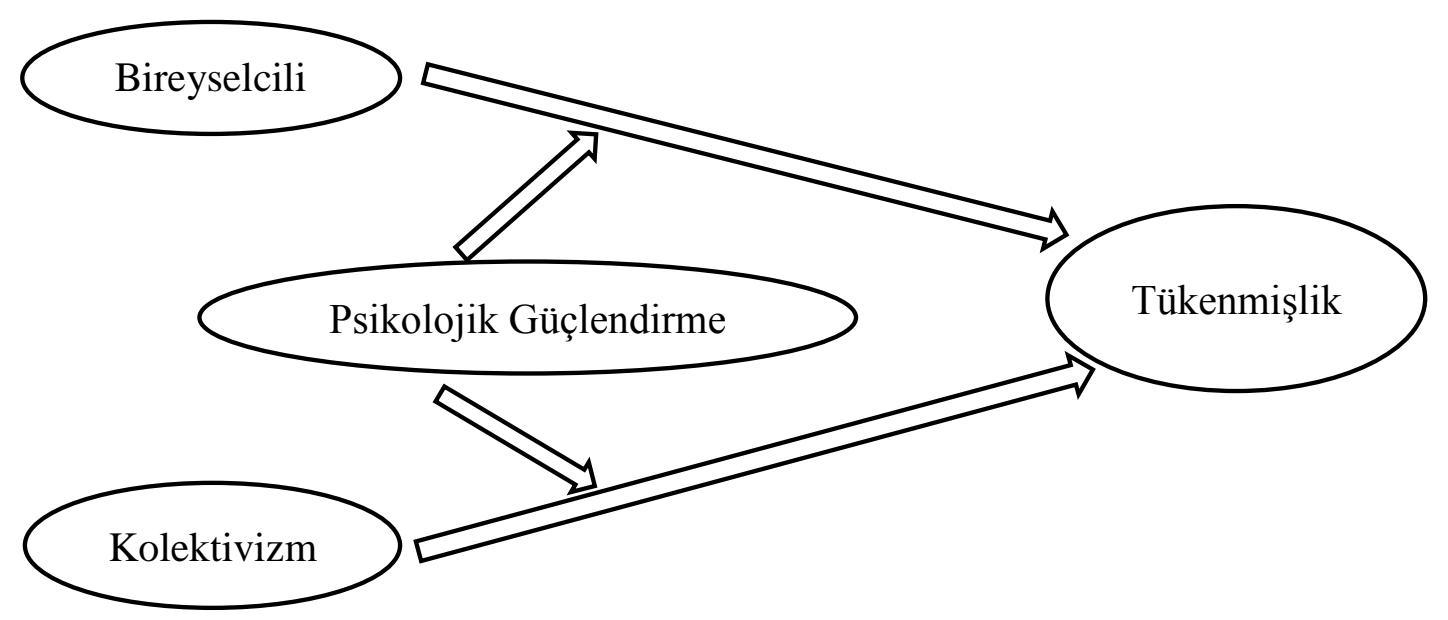

Şekil 2. Araştırma Model Resmi

\section{Yöntem}

\section{Araştırmanın Modeli}

Yukarıda şekil 2'de verilen model resminden de görüleceği üzere bireyselci ve kolektivist algıların tükenmişlik algısı üzerindeki etkisinde psikolojik güçlendirme algısının düzenleyici rolü öğretmenlerden oluşan örneklem üzerinde anket yöntemiyle ortaya konulmaya çalışılmıştır. 


\section{Çalışma Grubu}

Araştırmanın çalışma grubunu Sinop'ta kamu ortaokullarında görev yapan 207 öğretmen oluşturmaktadır. Araştırmada verilerini yüzyüze ulaşılan yaklaşık 400 öğretmenden toplanan veriler değerlendirilip ayıklandıktan sonra kalan 207 anket oluşturmaktadır. Basit tesadüfi örneklem yoluyla ulaşılabilen tüm öğretmenlere anketi dağıtılmış olup geri dönen anketler değerlendirilmiştir. Anketler incelendiğinde bazı anketlerde değerlendirilemeyecek kadar çok sorunun cevaplanmadığı gözlenmiştir. Anketin uygulandığı öğretmen sayısıyla geri dönen anketler ve kullanılabilir anketlerin sayısı karşılaştııılı̆̆ında öğretmenlerin tükenmişlik konusunda anket sorularına cevap vermeye isteksiz olduğu değerlendirilmiştir. Katılımcıların yaş ve cinsiyet sayı ve yüzdeleri Tablo 1'de sunulmuştur.

Tablo 1. Katılımcıların Yaş ve Cinsiyet Çapraz Tablosu

\begin{tabular}{llllll} 
& & & \multicolumn{2}{c}{ Toplam } \\
\cline { 3 - 5 } & & & Kadın & Erkek & \\
\hline Yaş & $\mathbf{1 8 - 2 5}$ & $\mathrm{N}$ & 36 & 24 & 60 \\
& $\mathbf{2 6 - 3 3}$ & $\mathrm{N}$ & 22 & 24 & 46 \\
& $\mathbf{3 4 - 4 1}$ & $\mathrm{N}$ & 24 & 30 & 54 \\
& $\mathbf{4 2 - 4 9}$ & $\mathrm{N}$ & 12 & 20 & 32 \\
& $\mathbf{5 0}$ ve üzeri & $\mathrm{N}$ & 6 & 9 & 15 \\
\hline Toplam & & $\mathrm{N}$ & 100 & 107 & 207
\end{tabular}

Tablo 1 incelendiğinde katılımcıların üçte birini 18-25 yaş grubu öğretmenler oluşturmaktadır (29 \%). 50 yaş üzeri katılımcı sayısı 15 olup toplam sayının \& 7,2'sidir. Kadın katılımcıların yarısına yakını kadındır (47,8 \%). Erkek katılımcı oranı \% 51.7'dir.

\section{Ölçme Araçları}

Araştırmada 5'li likert tipi aşağıda sunulan ölçme araçları kullanılmıştır.

\section{Tükenmişlik Ölçeği}

Araştırmada kullanılan bağımlı değişken olan tükenmişlik algısını ölçmek için Maslach ve Jackson (1981) tarafından geliştirilen ve Ergin (1992) tarafından Türkçe geçerlik ve güvenirlik çalışması yapılan duygusal tükenme ( 9 madde), kişisel başarı ( 8 madde), duyarsızlaşma (5 madde) adlı alt boyutlarıyla toplam 22 maddeden oluşan Maslach Tükenmişlik Ölçeği (MTÖ) kullanılmıştır. Ölçekte kişisel başarı boyutunun maddeleri (10-17. Maddeler) ters puanlanmıştır. Ölçekte yer alan maddelerden birkaçı “ Yolun sonuna geldiğimi hissediyorum" ve "İşim gereği karşılaştığım insanların bazı problemlerini sanki ben yaratmışım gibi davrandıklarını hissediyorum" şeklindedir.

\section{Bireysel ve Kolektivist Algı Ölçeği}

Araştırmada kullanılan bağımsız değişkenler olan bireyselcilik ve kolektivizm algısını ölçmek için Xie vd. (2006) tarafından geliştirilen Türkçe alanyazında Özbek (2010) tarafından kullanılan 8 maddeli bireysel eğilimler ve 8 maddeli kolektivist eğilimlerin ölçülmesini sağlayan iki faktörlü toplam 16 maddelik Bireysel ve Kolektivist Algı ölçeği kullanılmıştır. Ölçekte ters puanlanan madde yoktur. Ölçeğin maddelerinden birkaçı " Benim için mutluluk diğerleriyle zaman geçirmektir." ve "iş̧imi diğerlerinden daha iyi yapmam benim için önemlidir." şeklindedir.

\section{Psikolojik Güçlendirme Ölçeği}

Psikolojik güçlendirme aracı değişkenini ölçmek için anlam, yetkinlik, özerklik ve etki adlı 4 boyuttan oluşan toplam 12 maddeli Spreitzer (1992) tarafından geliştirilen ve Altındiş ve Özutku (2011) tarafından Türkçe geçerliği ve güvenirliği yapılan psikolojik güçlendirme ölçeği kullanılmıştır. Ölçekte ters puanlanan madde yoktur. Ölçeğin birkaç maddesi "Yaptığım iş benim için çok önemlidir" ve "Işsimle ilgili faaliyetleri yerine getirecek kapasiteye sahip olduğumdan eminim" şeklindedir. 
KILINÇ \& YENER - Çukurova Üniversitesi Eğitim Fakültesi Dergisi, 50(2), 2021, 1100-1126

Tablo 2. Ölçme Araçlarının Geçerlik ve Güvenirliği

\begin{tabular}{llllllllll}
\hline Ölçek Adı & $\begin{array}{l}\text { KMO } \\
\text { Testi }\end{array}$ & Sig & $\begin{array}{l}\text { Güv.Kat. } \\
\text { (Cron.Al } \\
\text { pha) }\end{array}$ & $\begin{array}{l}\text { Top. } \\
\text { Açık. } \\
\text { Oranı }\end{array}$ & $\begin{array}{l}\text { Fak.S. } \\
\text { Sayısı }\end{array}$ & $\begin{array}{l}\text { Top } \\
\text { ifade } \\
\text { Sayı }\end{array}$ & $\begin{array}{l}\text { Normal } \\
\text { Dağılım } \\
\text { Testi }\end{array}$ & Çarpıklık & Basıklık \\
\hline Tükenmişlik & 0,817 & 0,000 & 0,894 & $\% 49$ & 3 & 22 &, 001 &, 405 &, 025 \\
Bireyselcilik & 0,847 & 0,000 & 0,806 & $\% 48$ & 1 & 8 &, 000 &, 347 &,- 401 \\
Kolektivizm & 0,857 & 0,000 & 0,824 & $\% 42$ & 1 & 8 &, 000 &,- 254 & .324 \\
$\begin{array}{l}\text { Psikolojik } \\
\text { Güçlendirme }\end{array}$ & 0,842 & 0,000 & 0,942 & $\% 55$ & 4 & 12 &, 000 &,- 529 &,- 534 \\
\hline
\end{tabular}

Araştırmada kullanılan ölçme araçlarına ilişkin açıklayıcı geçerlilik analizi sonuçlarına bakıldığında tamamının KMO Barlett Küresellik testinde eşik değer olan ,80 (Field vd., 2000) değerinin üzerinde olduğu gözlenmiştir. 22 maddeli tükenmişlik ölçeğinin değişkeni \% 49'luk açıklama oranına sahip olduğu gözlenmiştir. Bireyselcilik ve kolektivizm eğilimlerini ölçmek için aynı ölçeğin iki alt boyutunun kullanıldığı ifade edilmişti. Her iki ölçeğin de KMO Barlett küresellik testi eşik değerinden yüksek olduğu gözlenmiştir. Bireyselcilik ölçeğinin \% 48, kolektivizm ölçeğinin \% 42 açıklama oranına sahip olduğu gözlenmiştir. Her iki ölçeğinde tek faktörlü 8 maddeye sahip olduğu gözlenmiştir. Psikolojik güçlendirme ölçeğinin KMO Barlett Küresellik sonucu eşik değerin üzerinde çıkmış olup $(, 842)$ açıklama oranı \% 55 olarak gözlenmiştir. Tablo 2'de Bireyselcilik ve Kolektivizm ölçeğinin iki alt boyutu ayrı bağımsız değişkenler olarak ele alınıp araştırma model resminden de görüleceği üzere ayrı ayrı değerlendirilmiştir.

Ölçeklerin tamamının güvenirlik sonuçları eşik değer olan ,70 Cronbach Alpha değerinin üzerinde gözlenmiştir.

\section{Verilerin Toplanması ve Analizi}

Araştırmanın çalışma grubunu oluşturan öğretmenlerden veriler 2019 yılının ekim ayında toplanmaya başlanmış olup 2020 yılının ocak ayında veri toplama faaliyeti bitmiştir. Verilerin analizine geçilmeden önce uygulanan normallik testinin sonuçlarına bakıldığında değişkenlerin tamamı anlamlı çıktığı için normallik gözlenmediği söylenebilir. Bununla birlikte normal dağılım testinin yorumlanmasında kullanılan basıklık ve çarpıklık testinin sonuçlarına Tablo 2'de bakıldığında tüm değerlerin eşik değerlerin $(-1,500-1,500)$ arasında kaldığı için parametrik testlerin uygulanmasının uygun olduğu söylenebilir.

\section{Bulgular \\ Değişkenler Arasındaki iliş̧ki}

Değişkenler arasındaki ilişkinin düzeyi ve yönünü ortaya koymak için uygulanan Pearson korelasyon testinin sonuçları Tablo 3'de verilmiştir.

Tablo 3. Değişkenler Arasındaki iliş̧ki Sonuçları

\begin{tabular}{llllll}
\hline & & PsiGüçlendirme & Tükenmişlik & Kolektivizm & Bireyselcilik \\
\hline PsiGüçlendirme & Pear.Kor. & 1 & & & \\
Tükenmişlik & Pear.Kor. &,$- 369^{* *}$ & 1 & & \\
Kolektivizm & Pear.Kor. &, $230^{* *}$ &,$- 342^{* *}$ & 1 & \\
Bireyselcilik & Pear.Kor. &,$- 213^{* *}$ &, $432^{* *}$ &,- 132 & 1 \\
\hline
\end{tabular}

**. 0,01 düzeyinde anlamlı korelasyon (2 kuyruklu).

Tablo 3'e bakıldığında yapılan Pearson Korelasyon test sonuçları Psikolojik güçlendirme ve tükenmişlik arasında orta düzeyde anlamlı ters ilişki $(r=-, 369, p<, 01)$, kolektivizm ve tükenmişlik arasında orta düzeyde ters ilişki $(r=-, 369, p<, 01)$, bireyselcilik ve tükenmişlik arasında orta düzeyde ters ilişki olduğunu ortaya koymuştur $(r=-, 369, p<, 01)$. 
Model Testi

Tablo 4. Araştırma Model Özeti

\begin{tabular}{|c|c|c|c|c|c|c|}
\hline $\mathrm{R}$ & $\mathrm{R}^{2}$ & MSE & $F$ & Df1 & Df2 & $P$ \\
\hline ,5694 & ,3242 & 0930 & 32,4663 & 3,0000 & 203,0000 & ,000 \\
\hline & $\beta$ & Sta Hata & $T$ & $P$ & $\mathrm{LLCl}$ & $\mathrm{ULCl}$ \\
\hline Sabit &,- 0394 & ,0216 & $-1,8208$ & ,007 &,- 008 & ,0033 \\
\hline Birey & 2994 & ,0571 & 5,2405 & ,0000 & 1867 & 4120 \\
\hline PsiGüç &,- 2345 & 0463 & $-5,0650$ & ,0000 &,- 3258 &,- 1432 \\
\hline Etkileşim &,- 4503 & 1084 & $-4,1548$ & 0000 &,- 6641 &,- 2366 \\
\hline
\end{tabular}

Etkileşim : $\quad$ Bireyselcilik $x$ Psikolojik Güçlendirme

- Araştırma modelinin test edilmesi için toplanan veriler IBM SPSS 22 programında tanımlanmış ve SPSS ' e entegre edilebilen Process 3.0 adlı bir makroyla analiz edilmiştir. Bireyselciliğin tükenmişlik üzerindeki etkisi ve bu ilişkide psikolojik güçlendirme düzenleyici değişkeninin rolünü ortaya koymaya yönelik yapılan test sonuçlarına bakıldığında Bireyselciliğin tükenmişliği anlamlı olarak arttırdığı $(\beta=, 30$; $P<0,01)$, psikolojik güçlendirmenin anlamlı olarak azalttı̆̆ı $(\beta=-, 23 ; P<0,01)$ gözlenmiştir. Bireyselcilik ve psikolojik güçlendirmenin etkileşiminin tükenmişlik üzerindeki etkisine bakıldığında daha önceden bireyselciliğin olumlu etkisini (tükenmişliği arttıran etkisi) yüksek bir katsayıyla $(\beta=-, 45 ; \quad P<0,01)$ olumsuza (tükenmişliği azaltan etki) dönüştürdüğü gözlenmiştir. Psikolojik güçlendirmenin düzenleyici olarak \% 45 düzeyinde tükenmişliğin azalmasına katkı sağladığı gözlenmiştir. Belirleme katsayısına bakıldığında $\left(R^{2}=, 32, p<0,01\right)$ bağımlı değişken olan tükenmişlik üzerindeki değişim \% 32 'sinin bireyselcilik ve psikolojik güçlendirme etkileşimi tarafından açıklanabildiği gözlenmektedir.

Tablo 5. Kolektivizm Tükenmişlik Psikolojik Güçlendirme Model Özeti

\begin{tabular}{|c|c|c|c|c|c|c|}
\hline $\begin{array}{l}\text { R } \\
, 4537 \\
\end{array}$ & $\begin{array}{l}R^{2} \\
, 2058\end{array}$ & $\begin{array}{l}\text { MSE } \\
1093 \\
\end{array}$ & $\begin{array}{l}\mathrm{F} \\
17,5353 \\
\end{array}$ & $\begin{array}{l}\text { Df1 } \\
3,0000\end{array}$ & $\begin{array}{l}\text { Df2 } \\
203,0000\end{array}$ & $\begin{array}{l}\mathrm{P} \\
, 000 \\
\end{array}$ \\
\hline & $\beta$ & Sta Hata & $T$ & $P$ & $\mathrm{LLCl}$ & $\mathrm{ULCl}$ \\
\hline Sabit &,- 0211 & ,0235 &,- 8952 & 3718 &,- 0674 & ,0253 \\
\hline Kolektivizm &,- 2801 & 0680 & $-4,1202$ & 0001 &,- 4141 &,- 1460 \\
\hline PsiGüç &,- 2410 & ,0506 & $-4,7600$ & ,0000 &,- 3409 & -,1412 \\
\hline Etkileşim &,- 0200 & 1299 &,- 1536 & 8780 &,- 2762 & 2362 \\
\hline
\end{tabular}

Etkileşim : Kolektivizm x Psikolojik Güçlendirme

Kolektivizmin tükenmişlik üzerindeki etkisi ve bu ilişkide psikolojik güçlendirme düzenleyici değişkeninin rolünü ortaya koymaya yönelik yapılan test sonuçlarına bakıldığında kolektivizmin tükenmişliği anlamlı olarak azalttığı $(\beta=-, 28 ; P<0,01)$, psikolojik güçlendirmenin anlamlı olarak azalttığı $(\beta=-, 24 ; \quad P<0,01)$ gözlenmiştir. Kolektivizm ve psikolojik güçlendirmenin etkileşiminin tükenmişlik üzerindeki etkisine bakıldığında daha önceden kolektivizmin olumsuz etkisini (tükenmişliği azaltan etkisi) düşük bir katsayıyla $(\beta=-, 02 ; P>0,01)$ sürdürdüğü (tükenmişliği azaltan etki) fakat bu ilişkinin anlamsız olduğu gözlenmiştir. Psikolojik güçlendirmenin bireyselcilik ve tükenmişlik arasında düzenleyici etkisi gözlenirken kolektivizm ve tükenmişlik arasında etkisi gözlenmemiştir. Hipotezler dikkate alındığında aşağıdaki sonuçlar gözlenmiştir.

$\mathrm{H}_{1}$ : Bireyselci eğilimler tükenmişliği arttırmaktadır. (DESTEKLENMişTiR)

$\mathrm{H}_{2}$ : Kolektivist eğilimler tükenmişliği azaltmaktadır. (DESTEKLENMişTiR)

$\mathrm{H}_{3}$ : Psikolojik Güçlendirme Bireyselci eğilimlerin tükenmişlik üzerindeki etkisini azaltmaktadır. (DESTEKLENMIŞTIR) 
$\mathrm{H}_{4}$ : Psikolojik Güçlendirme Kolektivist eğilimlerin tükenmişlik üzerindeki etkisini arttırmaktadır. (DESTEKLENMEMIŞTIR)

\section{Tartışma ve Öneriler}

Kaynakların korunumu kuramı çerçevesinde modellenen bireysel ve kolektivist eğilimlerin tükenmişlik üzerindeki etkisi ve bu etkide psikolojik güçlendirmenin düzenleyici rolünün sorgulandığı bu çalışmada dikkat çekici sonuçlar gözlenmiştir. Bireysel eğilimlerin tükenmişlik üzerinde anlamlı ve arttırıcı etkisi, kolektivist eğilimlerin tükenmişlik üzerinde anlamlı ve azaltıcı etkileri gözlenirken psikolojik güçlendirmenin sadece bireysel eğilimlerin etkisini düzenlediği gözlenmiştir. Kolektivist eğilimlerin tükenmişlik üzerinde güçlü bir etkisi gözlenmesine rağmen psikolojik güçlendirmenin düzenleyici rol oynamadığı gözlenmiştir.

Kasa ve Hassan'ın (2006) yapmış olduğu çalışmada kolektivizm ve bireyselciliğin tükenmişlik üzerinde düzenleyici rollerini sorguladıkları araştırmaya göre herhangi bir etki görülmemiştir. Bu yönüyle bu araştırma sonuçları Kasa ve Hassan'ın araştırmasını desteklememektedir. Kasa ve Hassan ilişkinin gözlenmeyişini tükenmişliğin belirleyicilerinin sosyokültürel faktörlerden çok işin bağlamının oluşturduğunu iddia etmektedir. Oysa Hofstede'in kültür taksonomisinde de iddia edildiği üzere bireylerin davranış ve algıları içinde bulunduğu toplumun özelliklerinden etkilenmektedir. Birçok çalışmada bireyselcilik bireyin kendini ifade edebilmesi, toplum içinde özgüven sahibi olması gibi bireysel özellikler çerçevesinde tanımlanmasına rağmen bireysel toplumlara bakıldığında dezavantajlarının olduğu görülebilir. Örnek vermek gerekirse bireysel bir toplumda kişisel çıkarların üstünlüğünden dolayı yardım, destek, geri besleme vb. hoşgörü davranışlarının kolektivist toplumlara nazaran daha nadir olduğu bilinmektedir. Kolektivist toplumlar bireysel toplumlarla karşılaştırıldığında bireysel özgürlüklerin daha az olduğu, cesaret, özgüven gibi boyutların daha düşük olduğu toplumlar olarak görülmesine rağmen paternalizmin getirdiği bir muhafaza, koruma ve yardım iklimi de gözlenir. Bu açıdan bu çalışmada psikolojik güçlendirmenin kolektivizmin tükenmişlik üzerindeki etkisinde düzenleyici rolü olmamasına rağmen kolektivizmin tükenmişlik üzerinde güçlü bir azaltıcı olarak rol oynadığı gözlenmiştir.

Tartışmaya açılması gereken bir diğer sonuç psikolojik güçlendirmenin bireysel eğilimlerde düzenleyici rol oynamasına rağmen kolektivist eğilimlerde rol oynamamasıdır. Kolektivist kültürün özellikleri itibariyle daha babacan, kucaklayıcı, koruyucu, muhafaza edici fonksiyonları bulunmaktadır. Kolektivist kültürde yaşayan bir bireyin yardıma ihtiyaç duyduğunda başvurabileceği birileri bulunabilir. $\mathrm{Bu}$ gibi kültürlerde bireyin çevresindekiler bazen birey yardıma ihtiyaç duymadan harekete geçebilmektedir. Psikolojik güçlendirmenin oluşturacağı birçok fonksiyon kolektivist toplumların özünde norm olarak zaten bulunmaktadır. Bu açıdan psikolojik güçlendirmenin etkisi kolektivist eğilimlerin etkisi karşısında sönük kalabilir çünkü çok benzer vurguya sahiptir. Bireyselcilik açısından bakıldığında bireysel eğilimlere sahip birey içinde yaşadığı toplumda diğer bireyleri potansiyel rakip olarak görerek açık vermemeye çalışır. Bu açıdan kendisinin iyiliğini isteyen veya kendisini rakip olarak görmeyen bireylerin psikolojik güçlendirme yapabileceği düşünülebilir. Bu şartlarda psikolojik güçlendirmenin daha etkin rolü olabilir. Psikolojik güçlendirmenin bireyselciliğin tükenmişlik üzerindeki etkisindeki düzenleyicilik rolü bu şekilde açıklanabilir.

Gelecekteki çalışmalar açısından bakıldığında bireyselciliğin yayıldığı toplumumuzda tükenmişliğin giderek daha yaygınlaşacağı öngörülmektedir. Örgüt içinde bağımlılı̆ı ve yardımlaşmayı arttıracak faaliyetler, yapısal güçlendirmeler alternatif stratejiler olarak sunulabilir. Ayrıca okullarda veya diğer eğitim kurumlarında öğrenci, öğretmen ve aile üçgeninin kurulması konusunda ciddi çalışmalar gerekmektedir. Eğitim sorumluluğunun sadece öğretmenlerin sorumluluğu olmadığı vurgulanmalıdır. Öğretmenlerin öğrencilerle belirli bir yaştan sonra ve sadece günün belirli saatleri arasında eğitim maksadıyla ilişki kurduğu dikkate alınırsa öğretmenin sorumluluğu kısıtlı kalmaktadır. Ayrıca öğretmenin okulda verdiği eğitimin devamı veya desteklenmesi aile tarafından evde sağlanmalıdır. Bu sayede öğretmenin üzerindeki psikolojik baskı azalabilir.

Araştırmanın sınırlıkları açısından bakıldığında araştırmanın hem bireysel ve kolektivist eğilimlerin görüldüğü Sinop'ta yapılması bir sınırlılığını oluşturmaktadır. Sadece ortaokul öğretmenlerinin dikkate alınması bir diğer sınırılığı oluşturmaktadır. Kullanılan ölçme araçlarına bakıldığında her bir ölçme 
KILINÇ \& YENER - Çukurova Üniversitesi Eğitim Fakültesi Dergisi, 50(2), 2021, 1100-1126

araçlarının birkaç versiyonu olması ve bu çalışmalarda en yaygınlarının kullanılması bir diğer sınırlılık olarak görülebilir.

Bu çalışmada Yükseköğretim Kurumları Bilimsel Araştırma ve Yayın Etiği Yönergesine uygun biçimde hareket edilerek bilimsel araştırma ve yayın etiğine aykırı hiçbir eylem gerçekleşmemiştir.

\section{References}

Altındiş, S. ve Özutku, H. (2011). Psikolojik Güçlendirmeyi Etkileyen Faktörler. Sosyal Bilimler Dergisi, 9(1), 161-192.

Baltaş, A. ve Baltaş, Z. (1987). Stres ve Başa Çıkma Yolları, Remzi Kitabevi, 4. Baskı, İstanbul, 1987,. 28.

Barutçu, E. and Serinkan C. (2013). Burnout Syndrome of Teachers: An Emprical Study in Turkey, 2nd Cyprus International Conference on Educational Research, (CY-ICER 2013), Procedia - Social and Behavioral Sciences 89 (2013) $318-322$

Bootzin, R. and Loftus, E. (1983). Robert Psychology, Today in Introduction. Random House, New York,1983.

Cherniss. C. (1980). Professional Burnout in human service organizations. New York: Praeger

Conger, J. and Kanungo, R. (1988). The empowerment process: Integrating theory and practice. Academy of Management Review. 13 (3), 471-482.

Corsun, D.L., and Enz, C.A. (1999). Predicting psychological empowerment among service workers: The effect of support-based relationship. Human Relations, 52 (2), 205-224.

Demerouti, E., Mostert, K. and Bakker, A.B. (2010). Burnout and work engagement: Through Investigation of the Independency of Both Constructs. Journal of Occupational Health Psychology, 15(3), 209-222.

Durak, H. Y. and Seferoğlu, S.S. (2017). Öğretmenlerin Tükenmişlik Duygusunun Çeşitli Değişkenler Açısından İncelenmesi, GEFAD, 37(2), 759-788.

Eren, E.(1998). Örgütsel Davranış ve Yönetim Psikolojisi. Beta Basım \& Yayınevi: İstanbul.

Ergin, C. (1992). Doktor ve hemşirelerde tükenmişlik \& Maslach tükenmişlik ölçeğinin uyarlanması. VII.Ulusal Psikoloji Kongresi Bilimsel Çalışmaları El Kitabı, 143-154. Ankara.

Freudenberger, H. (1975). The staff burn-out syndrome in alternative institutions. Psychotherapy, Theory, Research and Practice, 12(1), 73-82.

Freudenberger, H. (1980). Burnout: The high cost of achievement. New York: Anchor Press.

Hobfoll, S. E. (1989). Conservation of Resources: A new attempt at conceptualizin Stress. American Psychologist, 44, 513-524.

Hochwalder, J. (2007). The Psychosocial Work Environment And Burnout Among Swedish Registered And Assistant Nurses: The Main, Mediating And Moderating Role Of Empowerment. Nursing and Health Sciences. 9 (3), 205-211.

Hofstede, G. (1980). Culture's Consequences. Beverly Hills, CA: Sage Publications.

Hofstede, G. (1984). Culture's Consequences: International Differences In Work-Related Values. Beverly Hills, CA: Sage.

Kanter, R. M. (1993). Men And Women Of The Corporation (2nd ed.). New York, NY: Basic Books.

Karasek, R. A. (1979). Job Demands, Job Decision Latitude, and Mental Strain: Implications for Job Redesign. Administrative Science Quarterly, 24 (2): 285-308.

Kasa, M. and Hassan, Z. (2016). Burnout And Flow With Moderating Effect Of Individualism/Collectivism. A Study In Malaysian Hotel Industry. 3. Global Conference and Social Science-2015, GCBS-2015, 1617 December, Kuala Lumpur, Malaysian. 
KILINÇ \& YENER - Çukurova Üniversitesi Eğitim Fakültesi Dergisi, 50(2), 2021, 1100-1126

Kılınç, S. (2021). Asilik Eğilimi, Sanal Diğerkamlık ve Ahlaki Kimlik Davranışlarının Sanal Korsanlık Davranışları Üzerindeki Etkisi. Boyabat İktisadi ve İdari Bilimler Fakültesi E-Dergisi, 1(1): 1-15.F

Kirkman, B. L., Lowe, K. B. and Gibson, C. B. (2006). A Quarter Century Of Culture"S Consequences: A Review Of Empirical Research Incorporating Hofstede"S Cultural Values Framework. Journal of International Business Studies, 37(3), 285-320. https://doi.org/ 10.1057/palgrave.jibs.8400202

Laschinger, H.K.S., Finegan, J.E., Shamian, J. ve Wilk, P. (2003). Workplace Empowerment as a Predictor of Nurse Burnout in Restructured Healthcare Settings. Longwoods Review, 1(3):2- 11

Lévi, L., Bartley, M., Marmot, M., Karasek, R., Theorell, T., Siegrist, J., and Landsbergis, P. (2000). Stressors at the workplace: theoretical models. Occupational Medicine (Philadelphia, Pa.), 15(1), 69.

Lina Meng, R.N., Yi Jin, M.S.N., and Jiajia, G. M.S.N. (2016). Mediating and Moderating Roles of Psychological Empowerment, Applied Nursing Research, 30- 104-110.

Maslach, C.(2003). Job Burnout: New Directions in Research and Intervention. Current Directions in Psychological Science, Vol.12, 5, 189-192.

Maslach, C., and Jackson, S. E. (1981). The measurement of experienced burnout. Journal of Occupational Behavior, 2(1), 99-113.

Markus, H., and Kitayama, S. (1991). Culture and the self: Implications for cognition, emotion, and motivation. Psychological Review, 98, 224-253.

Meng, L., Jin, Y. and Guo, J. (2016). Mediating and/or Moderating Roles of Psychological Empowerment. Applied Nursing Research, 30, 104-110.

Neff, K. D. (2011). Self-compassion, selfesteem, and well being. Social and Personality Psychology Compass, 5(1), 1-12.

O’Brien, J. L. (2010). Structural Empowerment, Psychological Empowerment and Burnout in Registered Staff Nurses Working in Outpatient Dialysis. Unpublished Doctoral Thesis, The State University of New Jersey, 2010.

Özbek, M. F. (2010). Yatay ve Dikey Bireyselcilik ve Kolektivizm ile Para Etiği iliş̧kisi: Türk Kırgız Üniversite Öğrencileri Üzerinde Karşılaştırmalı Bir Araştırma, 10 (3), 23-42.

Spreitzer, G.M. (1995). Psychological Empowerment in the Workplace: Dimensions, Measurement, and Validation. Academy of Management Journal, 38(5), 1442-1465.

Thomas, K.W. and Velthouse, B.A. (1990). Cognitive Elements of Empowerment. Academy of Management Review, 15(4):666-681.

Xie, L. J., Chen, Z. and Roy, J. (2006). Cultural and Personality Determinants of Leniency in Self- Rating among Chinese People, Management and Organization Review, 2(2): 181-207

Wu, D. (2020). Relationship Between Job Burnout and Mental Health of Teachers Under Work Stress. Revista Argentina Clinical Psicologica, 29,1, 2020

Yener, S. ve Arslan, A. (2017). Iş'te Kadın. Çizgi Yayınevi: Konya

Zimmerman, B. J. (1995). Self-regulation involves more than metacognition: A social cognitive perspective. Educational Psychologist, 30, 217-221. 